Portland State University

PDXScholar

$11-1974$

\title{
An investigation of possible relationships between sex-role orientation, the motive to avoid success and the inhibition of aggression in women
}

Joan Dayger Behn

Portland State University

Barbara McDuffee Mecca

Portland State University

Follow this and additional works at: https://pdxscholar.library.pdx.edu/open_access_etds

Part of the Applied Behavior Analysis Commons, and the Experimental Analysis of Behavior Commons Let us know how access to this document benefits you.

\section{Recommended Citation}

Behn, Joan Dayger and Mecca, Barbara McDuffee, "An investigation of possible relationships between sex-role orientation, the motive to avoid success and the inhibition of aggression in women" (1974). Dissertations and Theses. Paper 2061.

https://doi.org/10.15760/etd.2060

This Thesis is brought to you for free and open access. It has been accepted for inclusion in Dissertations and Theses by an authorized administrator of PDXScholar. Please contact us if we can make this document more accessible: pdxscholar@pdx.edu. 
AN ABSTRACT OF THE JOINT THESIS OF Joan Darger Eehn and Barbara If Duffee Hecce for the Haster of Axts in Psychology presented November 19,1974 .

Title: An Investigation of Possible Relationships

between sex-role orientation, the Motive to

Avoia Shccess and the Iruibition of Aggression

in Women.

APPROVED EY HEMBERS OF THE THESIS COMMTMES:

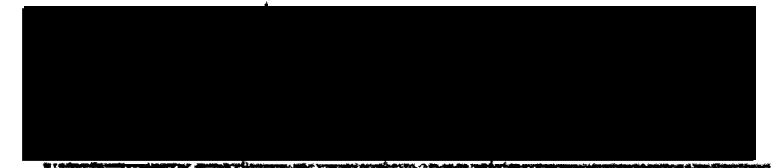

Walter Go Doofert/ Chaiman for IIs. Eenn

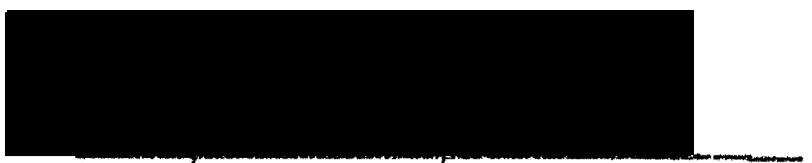

Engo/ haynara

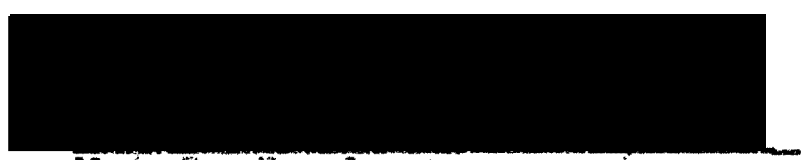

Fiex R. Reed

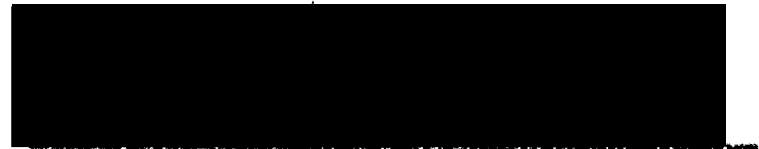

Hax Reed, Cheiman for 证s. Hecca

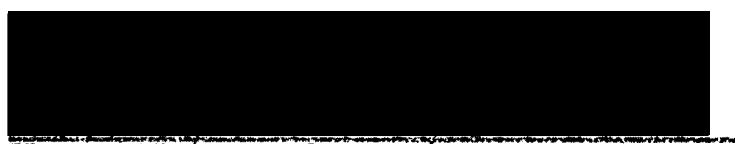

Hugangyard

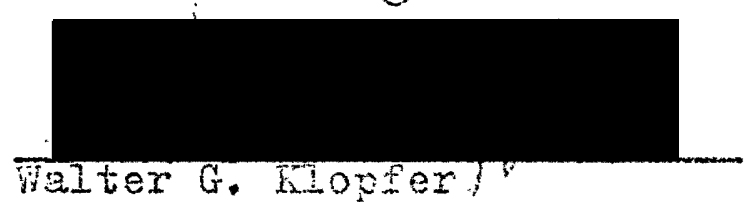

In this stuay, it was proposed that the extent to which an individual accepts the collection of attitudes, mannerisms, and abilities the culture endorses as being feninine or masculine (which we are referring to as sex-role orientation) is related to the appearence of irhibiting fears of social rejection and uneasiness about one's femininjty (which we reser to as the need or motive to avoid success). We furiner hypothesized that vomen 
interested in achievement, being less strongly sex-typed, would feel deviant and exposed as women and would be likely to place a premium on the maintenance of other feminine attributes.

Ever since Freud's time, the suppression of aggression has been identified as the very essence of femininity. This pinpointing of aggression as a particularIy differentiating quality between male and female has been maintained by some to the present. We proposed that this particularly feminine quality (which we refer to as fear of aggression) would appear more strongly in masculinelyoriented women.

Horner proposed in her original study that the liotive to Avoid success is a psychological barrier to achievement in women. When aroused, the motive to avoid success is a most effective suppressant of performance in a compeititive situation (especially if the competitor is masculine). This finding raised the suspicion in our minds that it might be the aggressive qualities inherent in competition that makes it seem especially incompatible with femininity. The aggressiveness of competition, of course, resides in the implicit set to defeat another person, to overpower an adversary, and to gain the psychological advantage. In order to obtain a high grade or graduate with distinction or secure the best job, you must defeat a peer.

We hypothesized finally, that not only would fear of 
aggression and Motive to Avoid Success (M-S) each be related to sex-role orientation, but that these two inhibitors would be positively correlated with each other.

Our Ss were 173 white college women from introductory psychology classes at Portland State University. To test our hypotheses that inhibition of aggression and Motive to Avoid Success would each be related to an individual's sex-role orientation, we used the following measures: The Gough femininity-masculinity scale and Franck Drawing Completion test to assess manifest and latent levels of Mi-F respectively; Horner's thematic cues to elicit Motive to Avoid Success; and a tachistoscopically-presented series of visual stimuli to assess the Sstendency to inhibit aggression.

Results indicated that fear of aggression is related to sex-role orientation in the expected direction, i.e., more masculinely-oriented women appear more likely to suppress aggression.

The in-S was also related to a particular constellation of sex-role orientations but not the expected set. Unlike the fear of aggression, high $M-S$ was related primarily to those individuals who held masculine orientations at the manifest level only.

Considering that both $[\mathrm{H}-\mathrm{S}$ and fear of aggression were related to masculine orientations in women, it was puzzling that these two measures were negatively correlated. 
AN INVESTIGATION OF POSSIBLE RELATIONSHIPS BETIEEN SEX-ROLE ORIENTATION, THE HOTIVE TO AVOID SUCCESS AND THE INHIBITION OF AGGRESSION IN WOHEN

\author{
by \\ JOAN DAYGER BEHN and BARBARA' MCDUFFEL MECCA
}

A Joint Theses submitted in partial fulfillment of the requirements for the degree of

MASTER OF ARTS

in

PSYCHOLOGY

Portland State University

1974 
Further research is suggested to clarify the finer discriminations of traits which evidently contribute to this unexpected result. 
TO THE OFFICE OF GRADUATE STUDIES AND RESEARCH:

The members of the two committees approve the joint thesis of Joan Dayger Behn and Barbara McDuffee Mecca presented November 19, 1974.

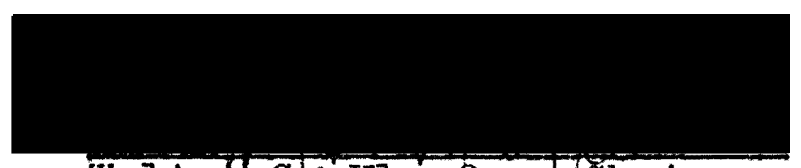

Walter G! Klopfer, Whairman for ins. Behn

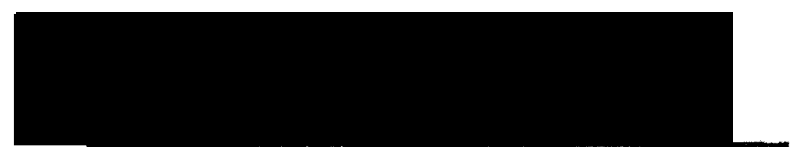
Hugo Naynare

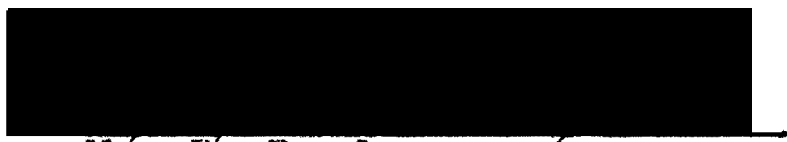

Pin R. Reed

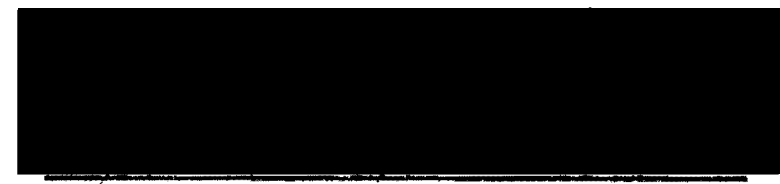

Wax R. Reed, Chairman for Ms. Inecca

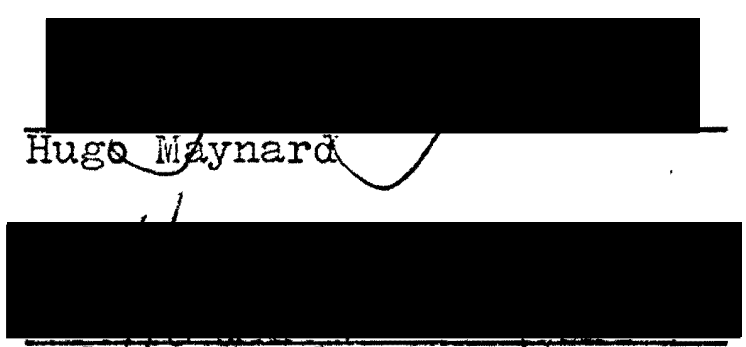

Walter G. Klopfer ol

APPROVED:

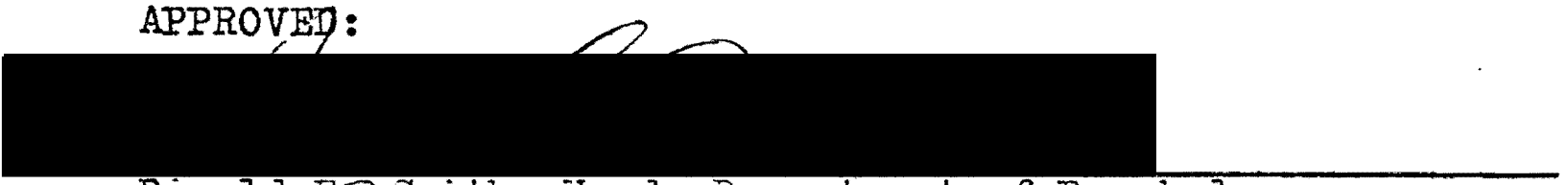

Ronald F.) Smith, Head, Department of Psychology

Datid T. Clark, Dean of Graduate Studies and Research

November 19, 1974 


\section{ACKNOWLEDGHENTS}

Without the active substantive and emotional support of my husband, Axel, and my children, Robin and Natalie, this would not have been possible. JDB

I wish to express my appreciation to each of my chilaren, Heg, Deborah, Nancy and Sara for their support, interest and especially their encouragement. Fithout their very reliable help and contributions this task would have been very difficult indeed.

BIIM 
TABIE OF CONTENTS

PAGE

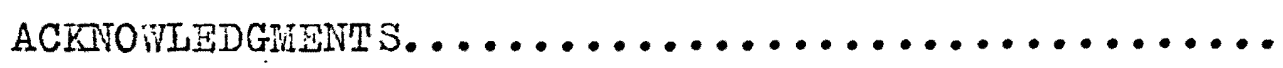

iii

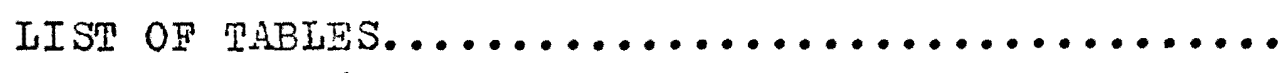

vi

IIST OF FIGURES...................... vii

CHAPTER

I INTRODUCTION, STATEMENT OF BACHGROUND AND FORITULATION OF THIL PROBIERI....... 1

II METHODS AND PROCEDURE............. 16

Subjects.................. 16

Procedure..................... 18

Sex-role ineasures

Gough.................. 19

Franck................. 20

Sex-role orientation......... 23

Motive to Avoid Success.......... 24

Fear of Aggression............ 25

Tachistoscope Perception Task..... 27

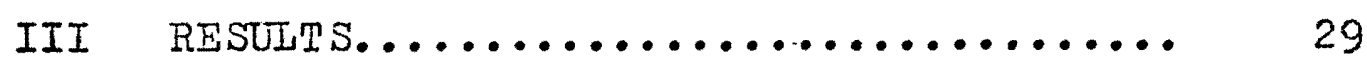

Franck.................... 29

Gough....................... 30

Sex-role orientation............ 31

Tachistoscope.............. 32 
CHAPTER

PAGE

III RESUITS

Ihotive to Avoid Success...........

Interrelationships.............

36

IV $\operatorname{DISCUSSION} \ldots \ldots \ldots \ldots \ldots \ldots \ldots \ldots \ldots \ldots \ldots \ldots \ldots$ 41

BIBIIOGRAPHY 49 APPENDIX. 
IIST OF TABLES

TABLE

PAGE

I Average recognition thresholds for each picture for the two threshold groups.... 33

II Average recognition thresholds for grouped

data for each of the two hypothesis groups............................ 34

III Test of significance of difference between various groupings of the sex-role orientation cells. 35

IV Means and standard deviations of fir-S scores for nine sex-role groups in increasing order of size of mean scores......... 37

$V$ ANOVA of difference between means of $M-S$ between the nine sex-role groups...... 37

VI M-S differences tested with the $t$ statistic.

VII Possible interrelationships of the experimental measures investigated with the use of Pearson's Product inoment........ 40 
IIST OF FIGURES

FIGURE

PAGE

1 Age distribution of subjects........... 16

2 Marital status of subjects............. 17

3 Ievel of father's education............ 18

4 Nine sex-role groups as derived for

Franck and Gough test score

distributions................ 23

5 Distribution of Ss Franck scores......... 29

6 Distribution of Ss Gough scores......... 30

7 Sex-role orientation distribution........ 31

8 Distribution of selected $36 \mathrm{Ss}$ in the

six sex-role cells of main interest... 32

9 Distribution of $\mathrm{H}-\mathrm{S}$ scores............. 36

10 Speculative comparison with Kagan

\& Moss' results.................. 43 


\section{CHAPTER I}

\section{INTRODUCTION}

Achievement behaviors in women have received particular attention in recent years because of governmental concern with sexual discrimination, the efforts of women's liberation groups, and the publicity given to both in the mass media. Proponents of a new emancipation for women focus such concern mainly on college women as the most able to meet the skill requirements of an advanced industrialized society and greatly expanded recruitment of college women into the professions has been undertaken.

We were interested in possible relationships between two dimensions of femininity... (manifest and latent sexrole orientations)..., the motive to avoid success, and fear of aggression in women. We hoped to find correlations between sex-role conflict, success phobia, and aggression conflict. Our interest springs from wonen's substantially lower level of achievement in "almost any area of intellectual activity where achievements can be compared -books and articles written, artistic productivity, and scientific achievements." (Haccoby, 1966).

Recruitment and a changed official position, however, can be less than effective. A report from a five-year 
study of student nurses at San Francisco Hedical Center, University of California, suggests that deliberate efforts to encourage women toward graduate work, attitudes of leadership, and an orientation to play an innovative role in the development of their profession, are not effective. (Davis \& Olesen, 1965). These researchers state that "overly rationalistic" efforts are not adequate and note that young college women are, including the most intellectually gifted among them, "peculiarly resistant" to urgings that they prepare themselves for higher academic or professional pursuits. An actual decline in professional aspirations was detected from entry to graduation five years later: It would appear that women's lack of achievement cannot be rectified by a simple change in social policy. The authors conclude that greater attention needs to be paid to the varieties of psychological forces that shape the role of women in American society.*

Although achievement is a central value in our culture, and behaviors related to the prediction of

* The criticism has been made that these particular young women, student nurses, have entered a traditionally and predominantly female profession and that women in such fields are rarely career committed. However, some researchers (Horner, 1972b; Schwenn, 1970; and Horner \& Rhoem, 1968) have found that the less sex-stereotyped, more highly career motivated and intellectually capable a woman is, the higher are her fears of social retaliation and the more likely she is to adjust her aspirations downward. The same decline in professional aspirations found in student nurses in 1965 is also found at Radcliffe in 1972 . 
achievement have a substantial history of study within academic psychology, this complexly motivated behavior is not understood as it is manifested--or not manifested--in women. A series of studies, using the Thematic Apperception Test (TAT) as a measure, have resulted in a theory base for achievement and an instrument for assessing motivation and predicting behavior. The measures that have evolved are: Need for achievement (n-Ach), need for affiliation ( $n-A f i l)$, and fear of failure (n-F). According to theories developed by $\mathrm{flc}$ clelland, Atkinson and others, a person's behavior in any given situation can be predicted if these elements and their relative strengths are known. This body of data has been useful in understanding and predicting male behavior but has given essentially no results in connection with women's behavior. This is most startlingly illustrated by perusing Atkinson's 800-page tome, Motives in Fantasy, Action, and Society that reports findings on male subjects only. A footnote explains that reported studies were either done on male subjects only or, in those cases where women were included in the experimental population, the female results were thrown out because they were so conflicted as to be unusable.

A measure of high $\mathrm{n}-\mathrm{Ach}$ assessed by way of the amount of achievement imagery present in stories written in response to TAT stimuli, usually is correlated with achievement behavior in men. This same measure does not 
correlate with achievement behavior in women. Under competitive conditions a measure of $n-A c h$ proves to be unreliable even with men unless a measure of $n$-Afil is also taken. With this additional measure one is able to predict achievement behavior in different situations-when the subject is working alone and when the subject is working in competition with another person. A man with a high n-Ach and a high n-Afil will perform at a high level on a solitary task, but on a competitive task there will be a drop in performance not found with a man who has a high n-Ach but low n-Afil. Still, this additional refinement does not account for the performance of women nor does a measure of fear of failure $(n-F)$.

Wany investigators in the recent past have attempted to shed light on the problem of understanding achievement as it is expressed or not expressed in women, usually with little success. Fontana (1970) suggested that a condition of achievement-oriented arousal evokes, in women, not only the motive to achieve, but also motives which dismupt achievement. But she was not able to isolate these motives. Iannotti (1971) attempted to find differences among low, medium, and upper academic achievers using the College Characteristics Questionnaire (CCI) and the 16 Personality Factor Questionnaire (16 PF). She was only able to conclude that any differences seem to be due to non-cognitive factors other than those measured by the 
$16 \mathrm{PF}$ and the $\mathrm{CCI}$.

A study conducted at Hunter College by Lesser et. al. (1963) did isolate one difference between achieving and underachieving women. When exposed to TAT stimuli, the achievers evidenced increased $\mathrm{n}$-Ach in response to pictures with female main characters while the underachievers evidenced increased $n-A c h$ in response to male pictures. The author interpreted this to mean that achieving women perceive intellectual goals as a relevant part of their ow female role, but underachieving women perceive intellectual achievement goals as more relevant to the male role.

Using this finding as a cue, Lipinshi (1965) tried to relate sex-role orientation to achievement. Her main thesis was that college women with various sex-role orientations, defined in terms of manifest and latent maculinity-femininity, would respond differentially to conditions of achievement arousal. To measure sex-role orientation Lipinski used categories developed by Lansky (1961) in which the Franck Drawing Completion Test (Franck DC) is given to assess latent sex-role orientation and the Gough Brief Test of Femininity (Gough) is used for a measure of manifest orientation.

Lipinski expected that women with a manifest masculine orientation would demonstrate an increase in n-Ach under arousal -- the typical pattern. Contrary to 
expectations, the greatest increase was found in the feminine oriented women and strongly masculine women actually showed a decrement from the neutral condition. Iipinski concluded that a measure of sex-role orientation and conflict was a relevant consideration in predicting women's behavior (if not in the direction she predicted) and should be studied further. She also postulated post hoc the possibility of a success phobia noting a prior finding that women who measure high in $n-A c h$ prefer and do better in classes low in achievement cues (McKeachie, 1961). Success phobia might be an inability to cope with intense competition with its "overtones of hostility".

Horner (1968a) suggests that an additional motive be assessed by the TAT procedure which she identifies as being the "need to avoid success" (n--S). In her study of 90 women and 88 men, Horner took measures of n-Ach, n-Afil, $n-F$, and $n--5$. She followed this assessment with measurements of performance under competitive and non-competitive conditions. For male subjects, her results supported past findings, that is, men as a group perform at higher levels under competitive conditions; a measure of $\mathrm{n}$-Ach is related to performance in non-competitive conditions; nen with both a high $\mathrm{n}-\mathrm{Ach}$ and high $\mathrm{n}-\mathrm{A} f \mathrm{il}$ show a decrement in performance in the competitive condition. For her female subjects, Horner!s results were also congruent with past findings -they were ambiguous and inconclusive - until the $n--S$ was 
considered. This was the only variable significantly related to the performance of women. The need to avoid success was found to be present in a large number of tested women (68\%) but in only $8 \%$ of the male subjects. This is a highly significant difference ( $p .0005)$.

Horner believes that the motive to avoid success is composed of two fears: (1) the threat of social rejection and (2) loss of one's own sense of self-esteem in regard to gender identity. But why -- in a culture that is strongly achievement oriented, that prepares boys and girls In the same educational system, and has specifically isolated increased feminine participation as a national goal since the National lianpower Council (1957) -- should women fear social rejection and loss of femininity? Tracing what has been historically viewed as feminine behavior and characteristics we find that Freud (1933) stated that the essence of femininity was repression of aggression. This attitude is maintained by Deutsch (1944) who further clarified it by adding that women can achieve intellectually only through the loss of valuable feminine qualities. Hargaret Head supports this refinement (1949), "...each step forward in work as a successful American... means a step back as a woman..." This has been maintained until at least 1966 when we find Haccoby stating that the girl who maintains qualities of independence and the active striving necessary for intellectual mastery, defies 
the conventions of sex-appropriate behavior and must pay a price: "a price in anxiety". It is from Maccoby that we get a familiar quote that many women feel accurately expresses their dilemma:

Nobody objects to a woman's being a good writer or sculptor or geneticist if at the same time she manages to be a good wife, a good mother, goodlooking, good-tempered, well dressed, well-groomed and unaggressive.

For each society there may be several convenient social definitions of masculinity and femininity. A particular individual within that society. may or may not conform to some social definitions of sex-role identity and experience a correlated low or high anxiety level. In our society many are now prepared to accept and in fact are actively encouraging a change in the female sex-role stereotype (on the explicit level). This new behavior, however, is a deviance from tradition, a form of risktaking, and puts a premium on the maintenance of other feminine attributes. It is our hypothesis that one of these attributes, the suppression of aggression, makes it particularly difficult for women to express the now-lauded achievement behaviors because there is a certain amount of aggressiveness involved in the very competitiveness required to reach high levels of achievement in our society.

Several researchers have noted that aggression is treated differentially in boys and girls by their parents. Sears (1961) noted with five-year olds, that boys were 
permitted to be more aggressive than girls and that by age 12, girls are more disturbed over aggressive behavior than boys. In a later extensive study of nursery school children and their parents (Sears, Rau \& Alpert, 1965) evidence was found that parents, whether consciousiy or not, create different overall strengths and styles of aggression in the two sexes. Boys display significantly nore antisocial aggression (direct physical attack, direct verbal attack, injury to objects, and mischief) than girls, while girls show slightly but not significantly more prosocial aggression (verbal disapproval and tattling) than boys. Sears additionally concludes, from his ow studies and others, that the "elaborate behavioral, attitudinal, and manneristic patterns" that people in our society characterize as being either masculine or feminine are absorbed quite early, by age $2 \frac{1}{2}-3$, and are highly resistant to change after that time.

Iooking at the early school years, we find that boys have significantly more "adjustment" problems than girls. They are more often behavior problems, underachievers, enuretic, have reading problems, speech problerns, and land more often in clinics. One eminently plausible explanation for this disparity of behaviors is that young children perceive school as a feminine place. Nearly all the teachers are female, non-aggressive behaviors are favored, and good grades are correlated with "good" behavior. Boys 
have difficulty finding a place in school when doing well is antithetical to masculinity.

Interestingly enough, the situation reverses itself in the high school years and the college years accentuate this reversal. High school is an increasingly masculine place and the college or university is a predominantly masculine environment. The teachers are predominantly male, and the behaviors demanded are successively more independent and aggressive. Girls are now the underachievers, the dropouts. They now have to face the same dilemma boys did earlier: The society presses for achievement but achievement also demands the acting out of sex-inappropriate behavior.

Kagan and Hoss (1962), in their explanation of some of the findings of 30 years of comprehensive and on-going assessment of a group oI individuals followed from birth (the Fels Research Institute longitudinal population), state that dependency is a stable trait for women (meaning that dependency in early childhood predicts dependency in the aduIt). One stable trait for men is ease of anger arousal. Some traits are stable for both sexes, e.g., spontaneity. Examples of unstable traits are, for men: dependency (dependency in a little boy does not predict dependency as an adult; for women: aggressiveness (aggressiveness in a little girl does not predict aggressiveness as an ault). The explanation Kagan and Hoss offer is: 
sex-typical behavior is likely to become stable because it is reinforced by members of the culture while sexatypical behavior is likely to be unstable because it is punished.

Observations of early training in the home and nursery school documented that young girls are subject to more severe socialization of aggression than are boys. A girl's behavior is gradually brought under control through the action of two sets of forces: (I) the content of the cultural definition of the ideal female influences the girl's "fantasied concept of how she should behave" and (2) the "pattern of rewards and punishments issued by parents, teachers, and friends act in concert to suppress both open forms of aggression and angry feelings."

Kagan and Moss found that aggression is strongly suppressed in women and that the majority of women in their longitudinal study did have an "aggression conflict", one measure of which was a significantly longer time taken to respond to tachistoscopically presented scenes of aggression. (This measure of aggression conflict was correlated with verbal denials of aggressiveness and delay in recalling aggressive scenes during adult assessment and to observer ratings of low overt aggressiveness in childhood.)

The feminine inhibition against the expression of aggression is of such magnitude, that consideration of sex 
and sex-role orientation is necessary in aggression related experiments. Milgram's famous experiment (Milgram, 1963) in which Ss were asked to administer increasingly severe shock to another person used only male subjects. In a later experiment, Buss (1963a) demonstrated that when the subject (shocker) and victim were of the opposite sex, more guilt and opposition could be elicited than with a same-sex pair when a negative statement regaraing the use of shock was read prior to the experiment. Buss went on (1963b and 1966) with investigations of behavioral sex-related differences. Using the aggression machine, as Milgram did, Buss found that the sex of both subject and victim were important. In the subject role, women as a group administer less shock to both men and women than men do. In the victim role, women receive less shock.

Leventhal and Shemberg (1968 and 1969) extended this work by examining the effect of sex-role adjustment, i.e., feminine-women and masculine-men. The finding most relevant to our work is that feminine women administered significantly more shock than did masculine-women. The finding that sex-role orientation is a relevant factor in predicting overt aggressive behaviors brings us full circle back to Lipinski's work.

For our study we propose to assess Horner's motive to avoid success and sex-role orientation as used by Iipinski. We would like to compare these two measures (as Horner 
suggests in the interpretation of her results) and, further, see if either or both of these are related to an "aggression conflict" - - to be measured by a task developed by Kagan and Hitoss (1962)* for the same purpose.

Soecific Hypotheses

In the following statements the first letters refer to the Franck DC status, the second designation the Gough masculinity-fernininity status. Capital letters, ii and F, refer to masculine \& feminine scores respectively, and the lower case letters $f$ and $m$ to intermediate range scores on a given test. (See fig. 4)

1. Those women with masculine sex-role orientations ( higher Hotive to Avoid Success than women with feminine sex-role orientations (FF, fmF).--

These women will be the most insecure in their sexrole orientations and presumably will be the least likely to risk the consequences of success.

2. Those women with masculine sex-role orientations (iill, Fil, fmil, and $\mathrm{MF}$ ) will evidence a higher recognition threshold for the four aggressive pictures than women with feminine orientations (FF, ImF).-- BEHN

Aggressive behavior in women is criticized by our society. Women with these masculine sex-role identities already feel censured. Therefore, it seems reasonable to

* See Chapter II, pages 23-26, for a description of the tachistoscope task. The Appendix, pages 59-61, includes the actual stimuli u.sed. 
expect that they will resist responding to the aggressive scenes.

3. Those women with a high recognition threshold for the four aggressive pictures will also have a high Hotive to Avoid Success.--JOINT

Women with high llotive to Avoid Success are fearful of risking the consequences of success and it is more likeIy they will resist recognizing the four aggressive pictures since they do not feel comfortable in aggressive situations.

4. Those women manifesting the sex-role orientations of FF and fmF will have a lower hotive to Avoid success than women with masculine sex-role orientations of $\mathrm{MM}$, FM, fmi, and MF.-- MECCA

Women who are most stereotyped in their sex-role identity are least interested in pursuing careers and can be expected therefore to have no reason to fear the consequences of scucess.

5. Those women manifesting the sex-role orientation of $\mathrm{FF}$ and $\mathrm{fmF}$ will have a lower recognition threshold for the four aggressive pictures, than wornen with sex-role orientations of BMI, FM, fmil, and IIF.- BEHN

Feminine women appear to show greater aggression than masculine women. Because these women ( $F F, f m F$ ) represent the most feminine part of the sample population, it is likely that they will recognize the aggressive pictures in the least time.

6. Those women having a low recognition threshold for the four aggressive pictures will also have a low Hotive to Avoid Success.-- JOINT 
Women with low aspirations for career success should be able to recognize the aggressive scenes easily since they are not under any pressure to defend their femininity.

7. The sex-role orientations of MH, FH, fmM, and NF will be correlated with a high Motive to Avoid Success and a high recognition threshold for the four aggressive pictures.-- JOINT

Women who are conflicted in their sex-role orientation will be least able to risk consequences of success and will most reluctantly respond to the aggressive scenes. Aggression is considered sex-inappropriate in women, consequently women who already feel deviant in their sexroles need to avoid aggressive behavior.

8. The sex-role orientations of FF and $f m F$ will be correlated with a low llotive to Avoid Success and a low recognition threshold for the four aggressive pictures.-- JOINT

These women are most confident in their sex-role orientation and presumably have little drive toward career goals. Therefore, they will have little fear of success consequences and will show low linotive to Avoid Success. This same group of women generally exhibit sex-appropriate behavior and can therefore more easily recognize sexinappropriate (aggressive) behavior on occasion. 


\section{CHAPTER II}

\section{METHODS AND PROCEDURE}

Subjects. The subjects were white college women from introductory psychology classes at Portland State University. By drawing our sample from this population, we have a group comparable to those in both Iipinski's and Horner's studies.

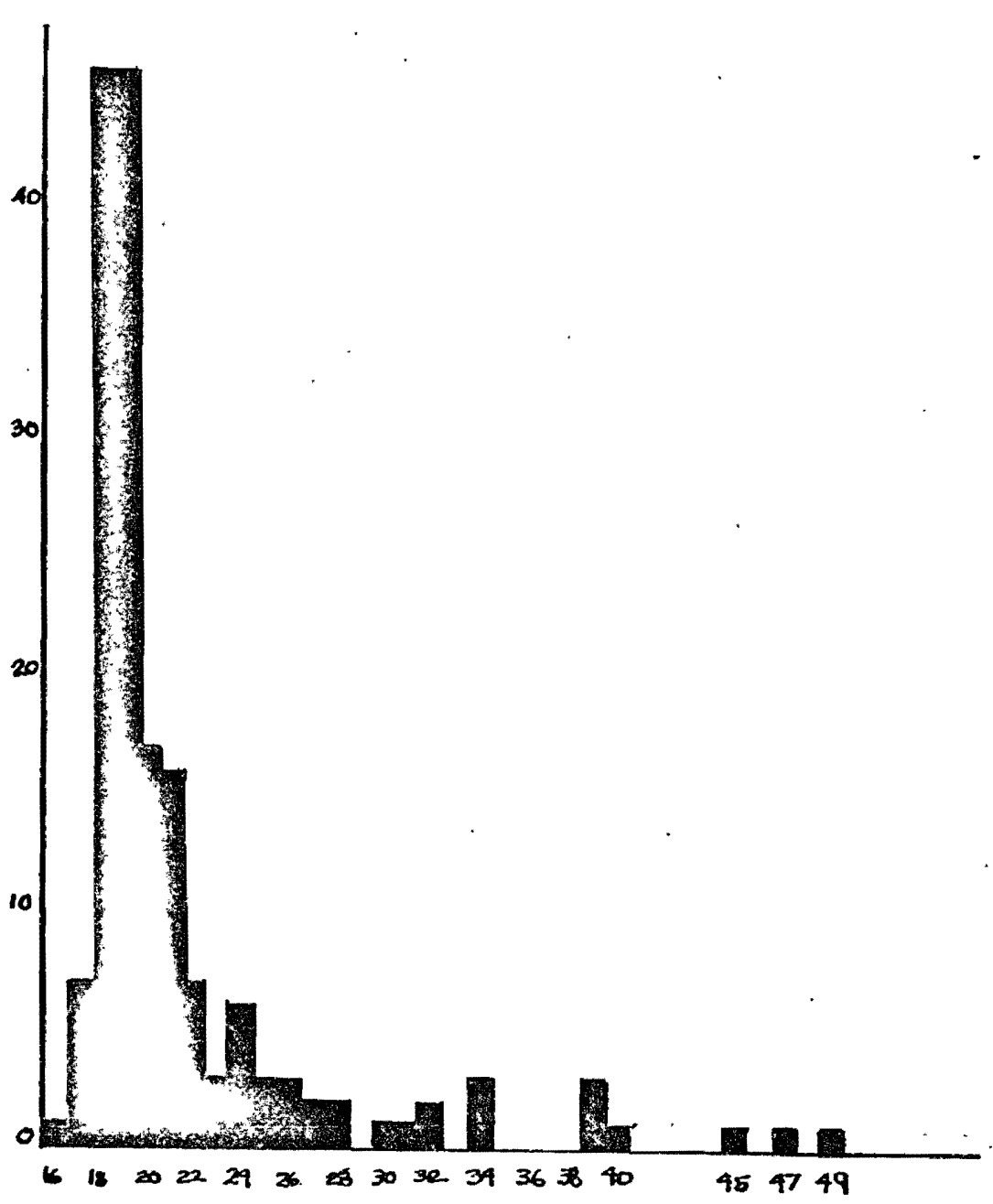

Figure 1. Age distribution of subjects. 
The original sample numbered 183. Some Ss were eliminated for not fully completing tests or for reasons of race, bringing the sample to $173 \mathrm{Ss}$. In age, the Ss ranged from 16 to 49. The mean for age was 19.92 years, with mode of 19 and median of 18. (See Figure 1.)

The Ss were primarily single, with approximately equal numbers of those being unattached or involved in a liason (engaged, going steady).

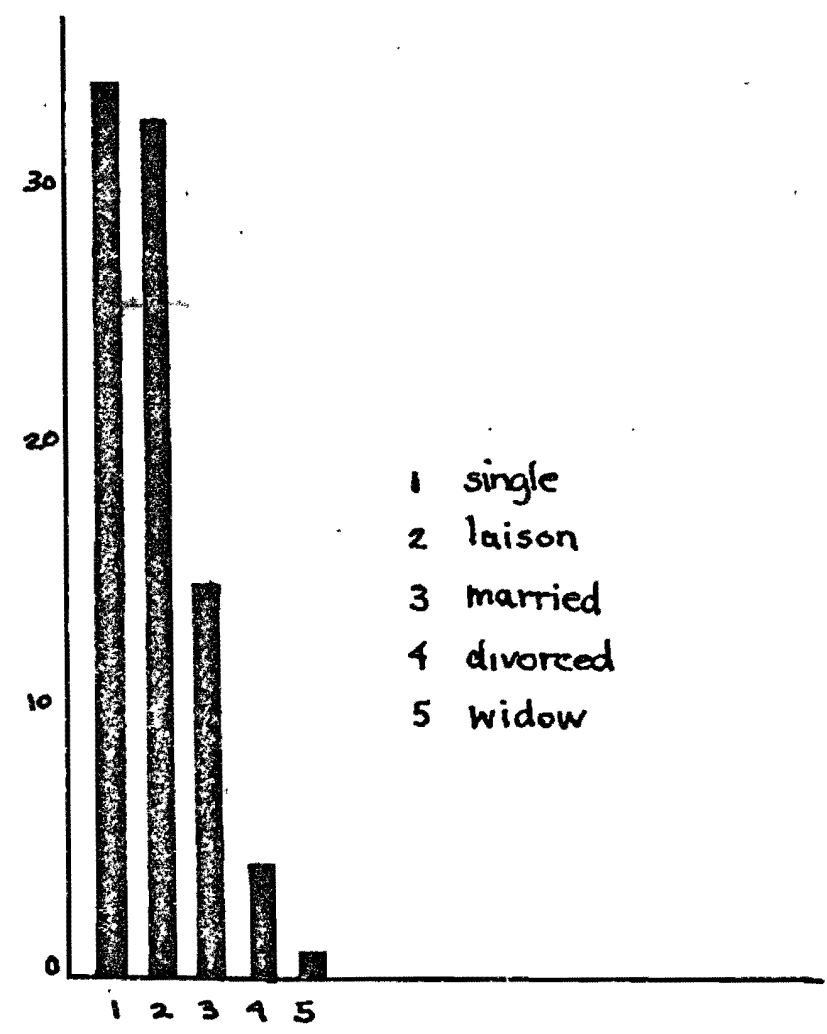

Figure 2. Harital status of subjects.

Fourteen of the married women had one child or more, four of those divorced had a child, and one single woman had a-child. (See Figure 2.) 
Socioeconomic class of the Ss, as estimated by level of father's education, is midale- and lower-middle class.

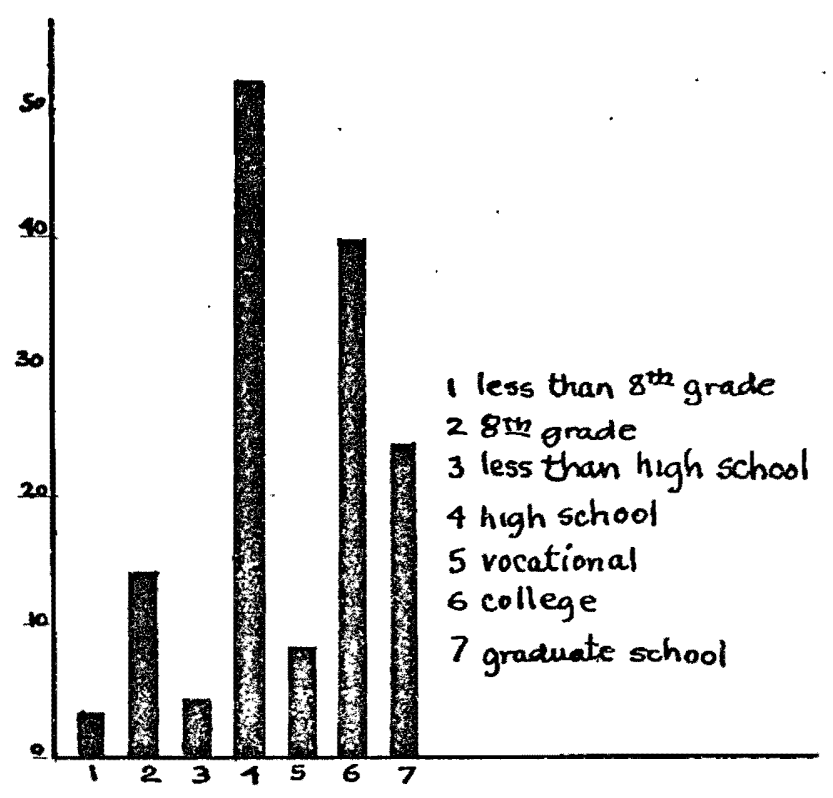

Figure 3. Level of father's education.

General Procedure. The sex-role conflict measures (Franck DC and Gough) and Horner's measure of ihotive to Avoid success were administered to Ss in a group. We both scored the two projective measures (Franck and Horner) and calculated the interscorer reliability using Kendall's Tau. The reliability of interscoring was .86 on the Franck and .87 on the Horner.

Included with this material were questions to inform us of age, socioeconomic class, marital status and whether the $S$ had children or not. To minimize Ss answering in biased directions, the measures were presented as research concerned with studying the relationship between verbal and 
non-verbal imaginative tasks and perception.

After the sex-role measures were scored, we asked a sample of women who fell into the cells of sex-role conflict ( $M M$, fmi, $F M, M F, ~ f m F$, and $F F$ ) to return to participate in the tachistoscope task. This was presented to Ss individually.

Measures of Sex Role

The Gough Brief Test of Femininity. Gough's aim in constructing this scale was to obtain an instrument that would differentiate males from females without being too obvious in content (as he felt the Strong and IMPI scales were) and which would be suitable for use with a normal. population. The beginning work on the scale began with items left-over from a political participation study that unexpectedly proved to differentiate males from females. To this pool were added items presumed to have some relationship to psychological femininity, either on empirical or speculative grounds. Through testing with high school and college students this pool was first reduced to 112 items. Further testing, again with high school and college students, resulted in 58 items that reveal significant differences between males and females. This method of scale construction Gough calls the "empirical technique". For this scale, usage indicates that for high school students, 5\% females fall below the male mean; for college 
students, $8 \%$ fall below the male mean. This femininity scale comprises one ( $f e$ ) of eleven scales on the California Psychological Inventory developed in this fashion. Gough reports several clusters of items on this scale. The largest factor he refers to as "an emphasis on clean white collar work, and a rejection of certain conventionally masculine roles". The second largest factor he describes as being "feelings of sensitivity, a tendency to respond to the nuances and atmosphere of social interaction as much as to the more concrete aspects". In the CPI Test Nanual, Gough gives a composite of the highly feminine individual as contrasted with the highly masculine individual as follows:

Feminine Masculine

Appreciative, patient, help- Outgoing, hard-headed, ambiful, gentle, moderate, per- tious, active, robust, \& severing \& sincere; as being restless; as being manipularespectful \& accepting of tive \& opportunistic in dealothers; \& as behaving in a ing with others; blunt \& conscientious \& sympathetic direct in thinking \& action; way. \& impatient with delay, indecision \& reflection.

The Gough scale has been used in conjunction with the Franck for four studies of sex-role orientation and is chosen in preference to the MIPI or Strong F-M scales because of the possibilities it offers us for comparing our work with prior efforts.

The Franck Drawing Completion Test. Thirty-six incomplete drawings are completed by the subject in any manner she chooses. The test is designed as a masculinity- 
femininity scale. Sex differences have been found to occur in the use of space, lines, and content. For example, openness vs closure, emphasis on internal elaboration vs external expansion, and passive vs active content are categories used in scoring.

The author claims that her test is a "measure of degree of acceptance of the individual's sex-role, conscious or unconscious." (Franck, 1949).

The scale was developed by Franck because she found existing $\mathbb{N}-\mathrm{F}$ scales to be inadequate in that "they are highly charged with cultural factors and hence their validity depends upon the absence of cultural change", (Franck, 1949). The direction of her investigation was taken from a study of the use of space by pre-adolescents (Erickson, 1951). Franck attempted to design a non-verbal measure sensitive to the found sexual differences in the use of space (spacial arrangements and configurations). After some unsuccessful attempts (Franck 1945 \& 1946) Franck was successful with a revised scale and obtained highly significant sex differences with a sample of college* students. It has been since standardized on citizens of eight countries and gives the same results.

Some indications of the success of Franck's avowed goal are to be found in a comparison study of Shepler's (1951). He found that the Franck test does as adequate a job of discriminating between men and women as does the 
MMPI $M-F$ scale, the Hi-F scale of the Strong Vocational Interest Blank (Forms if $\& \mathrm{~F}$ ), and the Terman-Miles Attitude Interest Analysis Test. However, while the Strong, MMPI, and Terman-Hiles measures correlate with each other the Franck does not correlate with any of them. The author concludes, in support of Franck's claim, the Franck DC test is apparently measuring different aspects of $\mathrm{F}-F$ than those measured by the other three instruments.

Reed (1957) has also found that the Franck has a "low insignificant correlation" with the M-F scale of the MPI and with the Draw-A-Person. Reed theorized, again in support of Franck's position, that the sexual difference assessed by the Franck DCT would be related to those orientations taken by the individuals at an extremely early age and would be related to unconscious modes of expression: nonverbal/kinesthetic/perceptual-motor. On the other hand, verbal statements measured by such instruments as the IMMI If-F would be related to later development and would be related to verbal/cultural expectations and the superego level of functioning. Reed found that a large difference between the $\mathrm{I}-\mathrm{F}$ as measured by the Franck DC and the MMPI $M-F$ was positively correlated with psychoses in women. This difference he took to mean a conflict existed between conscious and unconscious levels of $\mathrm{M}-\mathrm{F}$.

Several studies since Reed's have used the Franck DCT to measure "latent" as opposed to verbal measures of 
"manifest" II-F. Iipinski (1965), Sister Barbara (1971), Lansky (1961), and Hiller (1960) all report the Franck DCT to be a significant discriminator between men and women and yet not correlated with the verbal scales.

Urbina (1970) found that the Franck discriminated between male and female Ss at the .001 level of significance while only using the first 12 of the 36 item test. In the interest of brevity and to allow additional measures, an abbreviated version of the test (first 12 items) was used on the present stuay since it does not appear to impair the test's effectiveness.

Sex-role Orientation. Iansky (1960) has devised a means by which the sex-role identity of an individual is assessed in terms of congruence of scores on the Gough and Franck scales. The distribution of scores on both sets is divided into thirds, identified as $\mathrm{H}$ (most masculine), fm (average), and $F$ (most feminine) for the bottom, middle, and top thirds of the distribution for each test. By combining these three categories, it is possible to

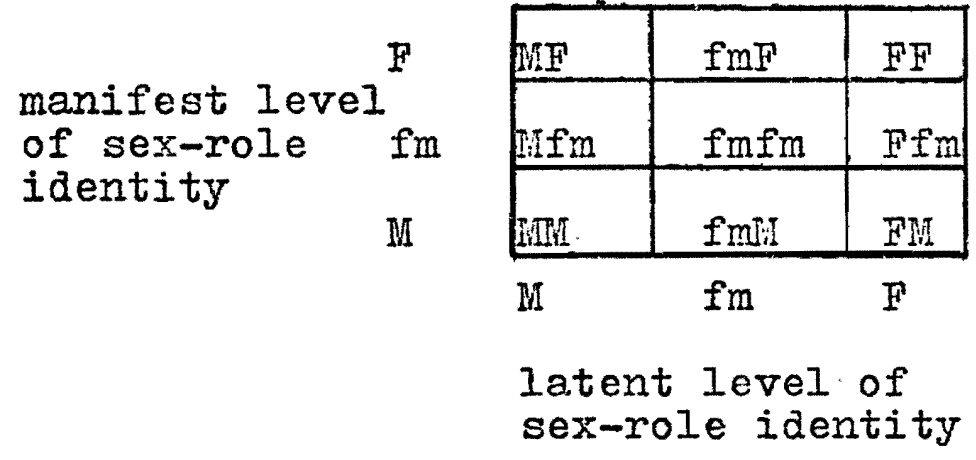

Figure 4. Nine sex-role groups as derived for Franck and Gough test score distributions. 
conceptualize congruence between the manifest and latent levels of sex-role identity as in figure 4.

The manifest level of sex-role identity is derived from the Gough test score distribution as described above, while the latent level sex-role identity is derived from the Franck test score distribution. The first letter in each of the nine cells in figure 4 refers to the latent level (Franck DC) of sex-role identity.

The fmfm category of figure 4 presumably reflects the norm in sex-role identity, i.e., the individual maintains optimal flexibility in coping with the demands of a complex world by drawing on both "masculine" and "feminine" orientations on both manifest and latent levels of awareness. The remaining categories of $\mathrm{hfm}, \mathrm{Ffm}$, fmi, $\mathrm{fmF}$ fall in some indeterminate middle range of greater flexibility than FF, FM, IFF, and MM (conflict groups) but less flexibility than the "ideal" fmfm group.

The Measure of Motive to Avoid Success (M-S). This measure is taken directly from Horner (1969) who reports it as being the only variable that relates to achievement behaviors. This motive is assessed by having the subject complete stories that are begun with the lines:

1. After first-term finals, Anne finds herself at the top of her medical-.-school class.

2. Anne is sitting in a chair with a smile on her face. 
Subjects are asked to write a brief paragraph about what happens to Anne next. The stories are scored for "motive to avoid success" if they express any negative imagery that reflects concern about doing well. Generally, such imagery falls into three categories: 1. strong fears of social rejection as a result of success, anxiety about becoming unpopular, unmarriageable and lonely. 2. guilt and despair over success and doubts about their femininity, or 3. simply deny that a woman could be so successful.

Fear of Aggression. There seems little doubt that psychological defense mechanisms as conceived in personality and clinical terms can influence perceptual recognition behavior. (Sauber, 1971) but the term "perceptual defense" has been the center of controversy. The term was first used by Bruner and Postman (1947) in relation to the finding that taboo words have high tachistoscopic thresholds. This and later studies have been criticized on methodological grounds. However, experiments more sound methodologically--that control for word frequency and other associative factors--continue to show that higher recognition thresholds are easily obtainable for disagreeable works (Goldiamond, 1958; Sauber, 1971).

Several issues remain for the interpretation of this stable empirical finding. The first objection that can be raised is that perceptual effects and response effects are confounded (Worthington, 1970). This is true but not 
of concern to us. Such a sorting out of effects would be interesting and desirable, although we do not wish to explore that problem in this study. We will maintain the same position as Coons \& Annis (1970) that, being interested in social learning, we can legitimately be content with a focus on the verbal response.

The second interpretive question concerns whether or not we can say that the individual with a high threshold is deviant and the individual with a low threshold reflects the norm in a given comparison. The lower threshold could just as well reflect a vigilant stance due to increased interest and the higher threshold reflect the norm rather than a defense.

A number of investigators have show that perceptual responses (auditory, kinesthetic \& visual) are subject to conditioning in the same way as motor responses. Mild shock appears to increase perceptual efficiency -- the "vigilance" effect (Adcock \& Nangan, 1970). With this in mind, Kagan and Moss' finding could be interpreted to mean that men as a group have a low threshold for aggressive scenes because they are more interested in, what is for them sex-appropriate behavior - and not mean that women have a high threshold because they have an aggression conflict as the authors interpreted it to mean.

Severe shock decreases perceptual efficiency, i.e., reduces the speed and liklihood of a perception. So that, 
with this information there are three possible responses: vigilant, unaffected, and defensive. Assuming that men demonstrate the vigilant effect, if we get two significantIy different thresholds for our two groups of women, it would seem reasonable to interpret the higher score as indicating some kind of inhibition.

Our procedure followed Kagan \& Moss' to allow comparisons to be made regarding the direction of response between our two groups of Ss.

Tachistoscopic Perception Tasls. The subject was seated at a tachistoscope and presented with a series of 14 test stimuli (See Appendix, pages 66-68). The subject was given the following instructions:

I am going to show you some pictures at a rapid rate, and I want you to tell me what is happening in the picture. Who are the people, are they male or female? What are their aoproximate ages; that is, are they old, middle-aged, young adult, or children? Finally, what is each person in the picture doing?

The instructions were intended to orient the subject to report objective facts about the pictures rather than a theme or inferences about the motives or feelings of the figures. The subject was then show three practice pictures to adapt her to the situation and to familiarize her with the responses required. Then the $S$ was shown the test stimuli at the fastest speed.

You will see 14 pictures again at slightly slower speed but in a different order. 
This was repeated for a total of seven times in three different random orders at exposures of .04, .08, $.10, .20, .40, .80$, and 1.0 secona. A check sheet was used to enable the experimentor to assess the $S$ 's identification of the test stimuli accurately (see Appendix page 69.) The $S$ was scored for the first trial in which she described accurately the sex, approximate ages, and content of the scene and after which she continued to produce correct responses at succeeding trials. This trial was designated as the S's recognition threshold.

Kagan \& lioss found that the control pictures generalIy had low thresholds for both sexes. However, both dependency scenes and aggression scenes occasioned"significant sex differences in ease of recognition (low threshold). For three of the four aggression scenes, the women had significantly higher recognition thresholds than the men. On all three dependency pictures, the men had significantly higher thresholds than the women. Additionally, a high threshold for recognition of aggressive scenes was correlated (in women) with low self-ratings of aggression, delayed recall of aggressive scenes, and inhibited aggression towards peers during childhood. (This task took approximately 30-45 minutes to complete with each subject.) 
CHAPTER III

\section{RESULTS}

Franck Scale. There were 12 raw measures collected from each subject that were scored for masculinityfemininity. The final score for each $S$ is a simple summing of the number of feminine drawings weighted by 3 . The range of possible scores is 0-36. In this case, the scores ranged from 6 to 33. The distribution of the women fell in a normal curve, sligntly skewed in the direction of mascu-

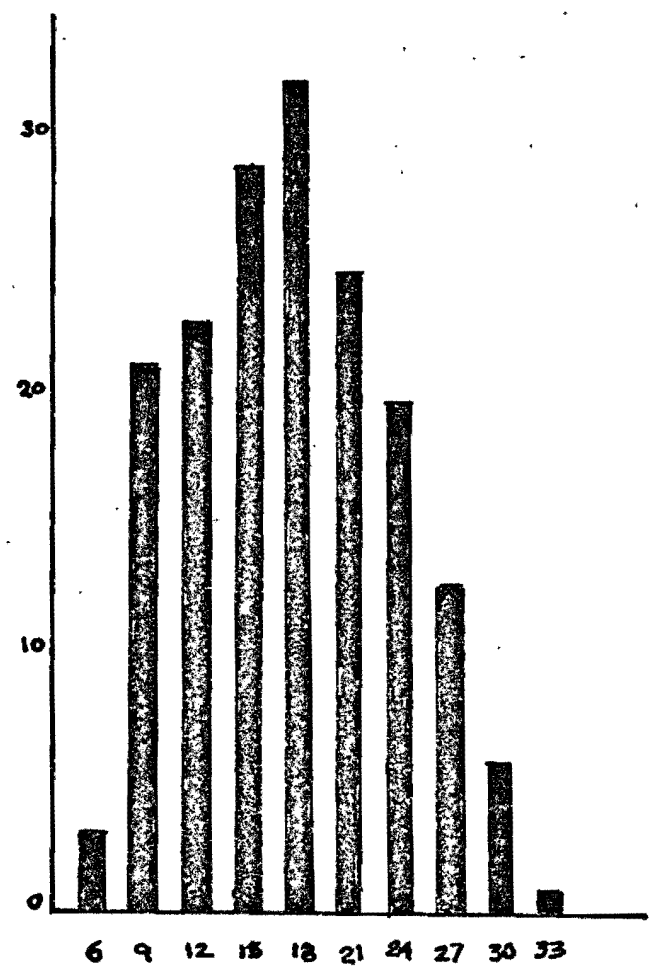

Figure 5. Distribution of Ss Franck scores. 
linity, a result that might be expected in a group of college women. The breakdom was $43 \% \mathrm{~m}, 46 \% \mathrm{fm}$, and $11 \% \mathrm{~F}$. (see Figure 5). The inter-rater reliability for scoring the Franck was . 86:

Gough Scale. Each true or false response was scored female or male, depending on the empirically-derived criterion key. The final score for this measure is the total number of feminine responses. The higher scores, as they are on the Franck, are more "feminine" -- in terms of empirical and social definitions of sex-role.

The Gough measure was characterized by a normal distribution, with a slight emphasis in the direction of femininity. The percentage of women falling in the $M$ sector was $16 \%$, in the neutral (fm) sector $53 \%$, and $31 \%$ fell in the $\mathrm{F}$ sector. (see Figure 6).

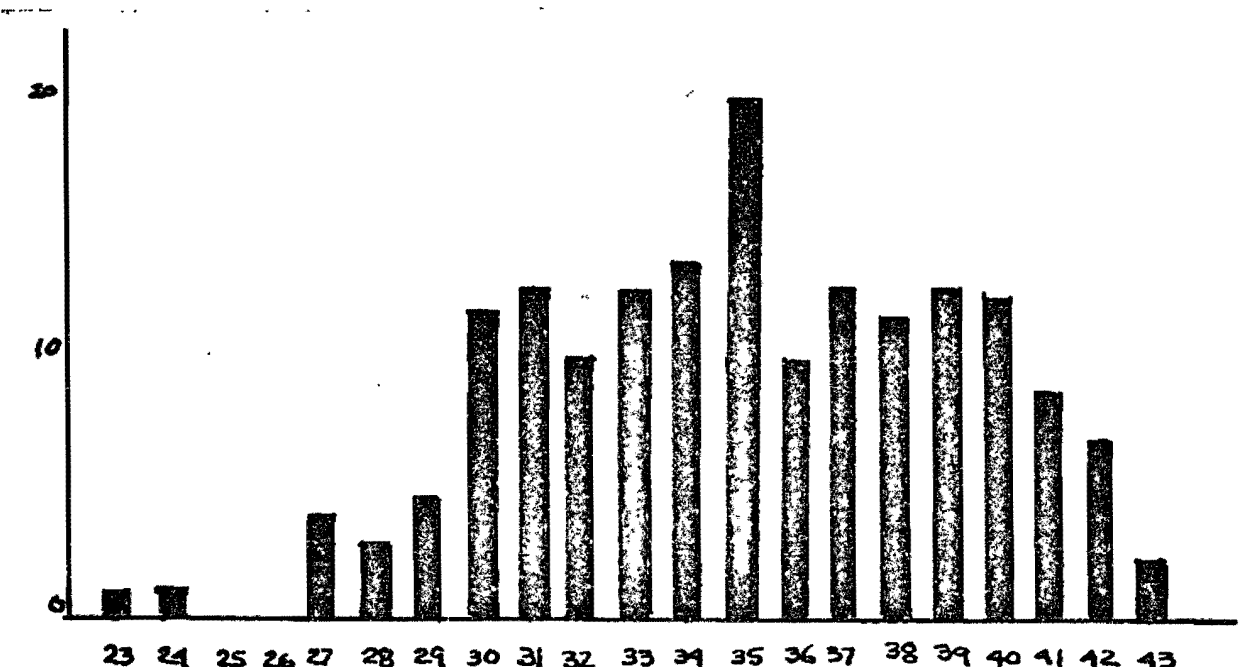

Figure 6. Distribution of Ss Gough scores. 
The mean Franck score (17.7) of the sample is lower than the mean of 22.7 reported for U.S. women by Franck and Rosen (1949) and the mean of 18.47 reported by Iipinski (1965). The mean Gough score (34.8) for this sample is essentially the same as the mean of $35^{\circ} .9$ reported by Lipinslii (1965) and the mean of 35.87 reported by Gough (1952).

Sex-role Orientation. Grouping the Ss by congruence of scores of the Franck and Gough measures (as outlined in Chapter II), the Ss were divided into the 9 sex-role orientations as follows: $12 \% \mathrm{MF}, 15 \% \mathrm{fmF}, 4 \% \mathrm{FF}, 29 \% \mathrm{~mm}, 20 \%$ fmfm, 5\% Ffm, 4\% MM, 9\% fmin, 2\% Fir. (see Figure 7).

\begin{tabular}{|c|c|r|}
\hline NF & fmF & FF \\
21 & 26 & 7 \\
\hline Irfm & fmfm & Ffm \\
51 & 34 & 8 \\
\hline WII & fmH & FM \\
7 & 15 & 4 \\
\hline
\end{tabular}

Figure 7. Sex-role orientation distribution.

Iansky's method of dividing Ss into 9 sex-role groups was simply to divide the obtained distribution of Franck and Gough scores into thirds, labeling the upper $1 / 3-$ feminine, the middle $1 / 3$ - neutral, and the remaining lower $1 / 3$ - masculine. Iipinski's results using these divisions were, for some hypotheses, inconclusive. In her discussion, Iipinski wonders if the $1 / 3-1 / 3-1 / 3$ divisions "adequately identify those who are actually conflicted." 
In this study, a modification of Iansky's method was tried. Since both the Franck and Gough have standardized scores, we used these scores to establish our breaking points rather than relyins on the particular distribution obtained in our sample of $173 \mathrm{Ss}$. (The disadvantage involved is the small number of Ss who fall into the extreme cells.) on the Franck, we used 0-15 to define masculine, 18-24 for neutral or flexible, and 27-36 for feminine. The Gough scores for masculine were 23-30, for neutral 31-39, and feminine $40-43$.

Tachistoscope. For this task 36 Ss were selected who fell into the 6 cells of main interest: $\mathrm{IF}$, fmF, FF, MM, friir, FM. The Ss were distributed as noted in Figure 8.

\begin{tabular}{|c|r|r|}
\hline$M F$ & fmF & FF \\
7 & 9 & 4 \\
\hline $\mathrm{MM}$ & fmM & FM \\
6 & 7 & 3 \\
\hline
\end{tabular}

Figure 8. Distribution of selected 36 ss in the six sex-role cells of main interest.

The Ss were each show a series of 14 line-drawings of people in various situations. The 14 stimuli contained 4 aggression scenes, 3 dependency scenes, 2 romantic scenes, 2 physical harm pictures, and 3 neutral situations. The scenes are briefly described in Appendix page 66, and presented in the Appendix, pages 67 and 68. A list was provided $E$ to aid in maintaining the same standards for 'recognition' in a.I Ss. The scoring list is presented 
in the Appendix, page 69.

The $S$ was scored for the earliest trial at which a given stimulus is identified correctly, and continued to be identified correctly.

The average recognition thresholds for the scenes are presented in Table $I$.

TABIE I

AVERAGE RECOGNITION THRESHOIDS FOR EACH PICTURE FOR THE TWO HYPOTHESIS GROUPS

\begin{tabular}{|c|c|c|c|c|}
\hline Picture & & $\begin{array}{l}\text { FH, } \mathrm{MP} \\
\mathrm{MNH}, \mathrm{Im}, \mathrm{I}\end{array}$ & $F F, f m F^{2}$ & $\begin{array}{l}t \text { one- } \\
\text { tailed }\end{array}$ \\
\hline Aggression & $\begin{array}{r}1 \\
2 \\
13 \\
14 \\
\end{array}$ & $\begin{array}{l}6.48 \\
3.57 \\
6.22 \\
5.00 \\
\end{array}$ & $\begin{array}{l}6.46 \\
3.08 \\
5.85 \\
4.54 \\
\end{array}$ & $\begin{array}{r}.02 \\
.93 \\
.88 \\
1.03 \\
\end{array}$ \\
\hline Dependency & $\begin{array}{l}3 \\
4 \\
5 \\
\end{array}$ & $\begin{array}{l}5.96 \\
6.04 \\
5.61 \\
\end{array}$ & $\begin{array}{l}5.62 \\
5.38 \\
5.54\end{array}$ & $\begin{array}{c}.73 \\
1.72 * * \\
.16\end{array}$ \\
\hline Sex & $\begin{array}{l}6 \\
7 \\
\end{array}$ & $\begin{array}{l}6.30 \\
3.78 \\
\end{array}$ & $\begin{array}{l}5.62 \\
3.92 \\
\end{array}$ & $\begin{array}{c}1.52^{*} \\
.30 \\
\end{array}$ \\
\hline Harm & $\begin{array}{l}8 \\
9 \\
\end{array}$ & $\begin{array}{l}4.39 \\
5.83 \\
\end{array}$ & $\begin{array}{l}4.54 \\
5.23 \\
\end{array}$ & $\begin{array}{r}.34 \\
1.84 * * \\
\end{array}$ \\
\hline $\begin{array}{r}\text { Control } \\
* .10 * .05 \\
\end{array}$ & $\begin{array}{l}10 \\
11 \\
12 \\
5\end{array}$ & $\begin{array}{l}4.91 \\
5.13 \\
4.96\end{array}$ & $\begin{array}{l}4.54 \\
5.46 \\
4.85\end{array}$ & $\begin{array}{l}.96 \\
.69 \\
.31\end{array}$ \\
\hline
\end{tabular}

The original hypothesis called for grouped aggression and dependency recognition thresholds. Since significantIy different means were found to occur with scene $\mathrm{S6}$ and H9, the data for Sex, Harm, and Control were also grouped and tested. The average recognition thresholds for the grouped 
data are given in Table II.

Since the hypothesis groupings did not obtain significant results in relationship to $\mathbb{M}^{-S}$ (although they did in relation to aggression on the tachistoscope task), but other groupings did, it was felt advisable to check these groupings in regard to Tachistoscope data also.

\section{TABLE II}

AVERAGE RECOGNITION THRESHOIDS FOR GROUPED DATA FOR EACH OF THE THO HYPOTHESIS GROUPS

\begin{tabular}{|c|c|c|c|}
\hline Picture & $\begin{array}{ll}\text { MIII, } & \text { fmII } \\
\text { III, } & M F\end{array}$ & $\overline{F F}, f m \bar{F}$ & $\begin{array}{l}\text { t one- } \\
\text { tailed }\end{array}$ \\
\hline Aggression & $5 \cdot 32$ & $4 \cdot 98$ & $3.24 * * * *$ \\
\hline Dependency & 5.87 & 5.51 & 1.44 \\
\hline Sex & 5.2 & 4.80 & .76 \\
\hline Harm & 5.11 & 4.88 & .66 \\
\hline $\begin{array}{l}\text { Control } \\
* * * * .005\end{array}$ & 5.0 & 5.0 & -- \\
\hline
\end{tabular}

The results, (see Table III) were not significant with the single exception of pest \#3 (aggression) which remained significant with the removal of the maverick* IIF group but at a lesser level (.01 vs .005).

*The MF group was termed maverick by Iipinski because the results for this group conflicted with those of other women having manifest feminine sex-role orientation. 
TABLE III

TESTS OF SIGNIFICANCE OF DIFFERENCE BETVEEN

VARIOUS GROUPINGS OF THE SEX-ROIE

\begin{tabular}{|c|c|c|c|c|c|}
\hline \multirow[b]{2}{*}{ Test if } & Sex & \multicolumn{2}{|c|}{ IION CELSS } & \multirow{2}{*}{\begin{tabular}{|c} 
Aggres- \\
sion \\
$t$ \\
\end{tabular}} & \multirow{2}{*}{$\begin{array}{c}\text { Depen } \\
\text { dency } \\
t \\
\end{array}$} \\
\hline & Groux 1 & Group 2 & $\mathrm{df}$ & & \\
\hline $1-2$ & $\begin{array}{l}\text { Min, frnil, } \\
\text { SM, IMF }\end{array}$ & $\mathrm{FF}, f m F$ & 34 & $3.24 * *$ & 1.05 \\
\hline $3-4$ & 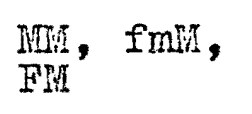 & $F F, f m F$ & 27 & $2.43 *$ & .89 \\
\hline $5-6$ & ${ }_{\text {Fin }}$, fmis, & FF, $f m F$, & 34 & .55 & .46 \\
\hline $7-8$ & MnI, fmil & $F F, \quad f m F$ & 24. & .98 & .87 \\
\hline $9-10$ & $\begin{array}{l}\text { IIIS, FHI } \\
\text { (Gough) }\end{array}$ & $F F, M F$ & 18 & 1.11 & .69 \\
\hline $11-12$ & $\begin{array}{l}\text { MF , IMI } \\
\text { (Franck) }\end{array}$ & $F F, F M$ & 18 & .99 & .41 \\
\hline $13-14$ & $I M I$ & $F F$ & 8 & .02 & 1.09 \\
\hline
\end{tabular}

Hotive to Avoid Success. Using the new scoring manual, Motive to Avoid Success was found to be present in $92 \%$ of the Ss and absent in $8 \%$ of the Ss.

The stories written by each $S$ in response to the two verbal cues were scored for $\mathrm{H}-\mathrm{S}$ using the new scoring manual developed by Horner, et. al. (1973). There are 5 categories which may be scored for presence of $\mathrm{li}^{-S} \mathrm{~S}$ and one category which is scored for absence of $\mathrm{H}^{-S}$. The six categories are summed for the final score. Consequently, the range of possible scores was -4 to +16 . Scores in this study ranged 
from -4 to +13 . Some degree of $\mathrm{N}-\mathrm{S}$ was present in $92 \%$ of the Ss. Using the natural cutting points that occurred in this sample, this breaks down as follows: of those in which $\mathrm{Ih}-\mathrm{S}$ was present; low $\mathrm{H}-\mathrm{S} .25$, medium $\mathrm{H}-\mathrm{S} .29$, and high $\mathrm{MI}-\mathrm{S} \cdot 33$.

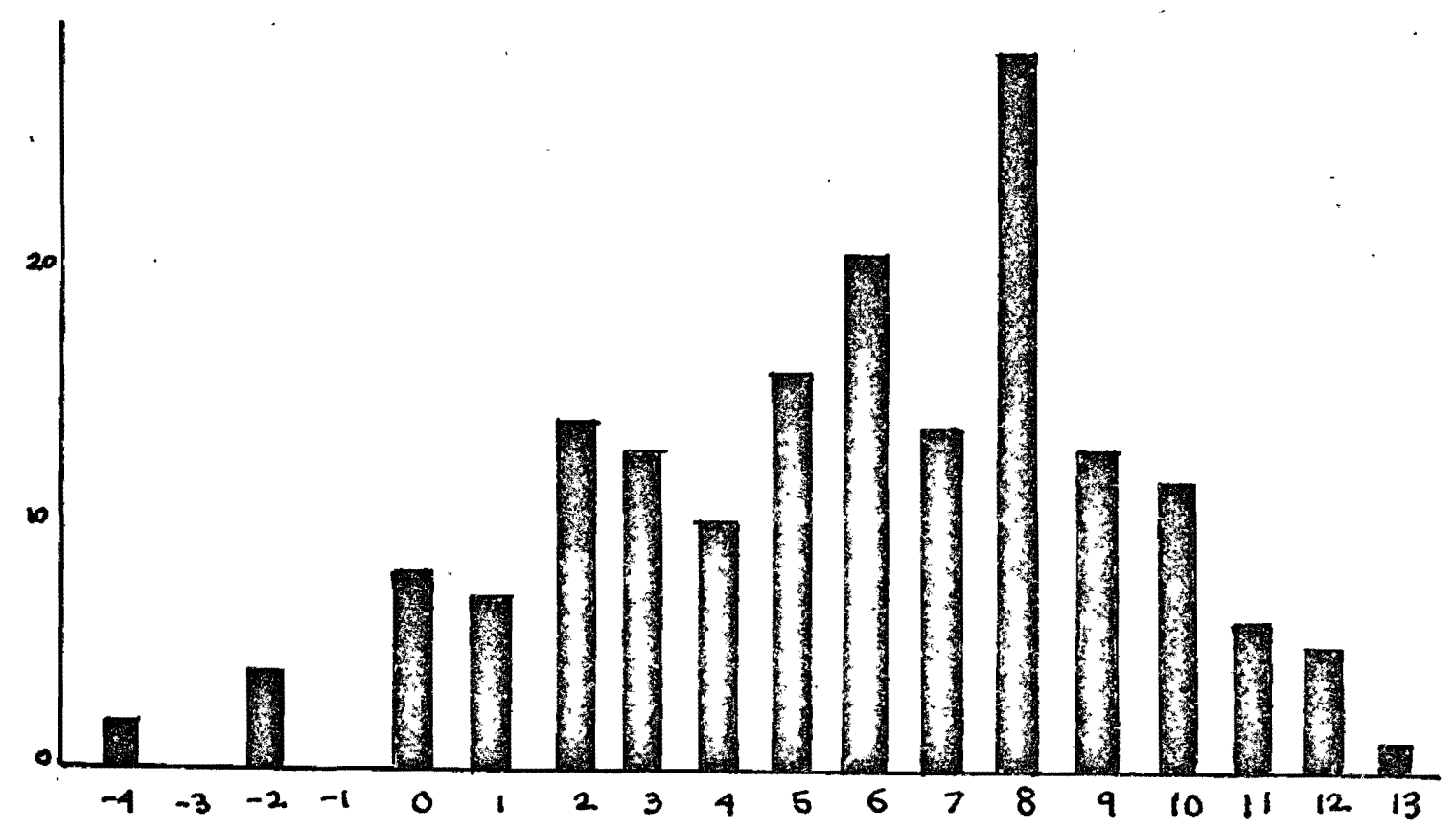

Figure 9. Distribution of M-S Scores

Means and standard deviations were computed for all sex-role groups IIIS scores (see Table IV).

The $t$ statistic was used to analyze the data in various combinations of sex-role groups. (see Table VI). A test of Hypothesis 1 (IH, fmit, $M F, F M$ vs FF, fmF) and 4 (FF, ImF vs IIII, fmH, IIF, Fil) produced no significant differences. 
TABIE IV

MEANS AND STANDARD DEVIATIONS OF M-S SCORES FOR NINE SEX-ROIE GROUPS IN INCREASING ORDER

OF SIZE OF HEAN SCORES

\begin{tabular}{|l|l|l|r|}
\hline Sex-role Group & \multicolumn{1}{c}{ X } & SD \\
fmfm & 4.7941 & 3.298 & 34 \\
Ffm & 5 & 2.6185 & 7 \\
MF & 5.125 & 4.456 & 8 \\
Mfm & 5.5714 & 3.5126 & 21 \\
fmF & 5.6274 & 3.4466 & 51 \\
fmin & 6.48 & 3.4224 & 26 \\
Fin & 6.66 & 2.599 & 15 \\
MHI & 7 & 3.675 & 4 \\
\hline
\end{tabular}

An Analysis of Variance for independent means produced an $\mathrm{F}$ of 1.32. For eight degrees of freedom, the level of confidence was .25 , which is too high to be considered significant.

\section{TABIE V}

ANOVA OF DIFFERENCE BETHEEN MEANS OF MI-S BETHEEN THE ININE SEX-ROLE GROUPS

\begin{tabular}{|l|r|r|r|r|r|}
\multicolumn{1}{c}{ Source } & \multicolumn{1}{c}{ SS } & df & ms & P & P \\
\hline Total & 2085.087 & 172 & - & - & \\
Between groups & 126.1935 & 8 & 15.774 & 1.32 & .25 \\
Within groups & 1958.8935 & 164 & 11.945 & - & \\
\hline
\end{tabular}


TABIE VI

M-S DIFFERENCES TESTED WITH THE $t$ STATISTIC

\begin{tabular}{|c|c|c|c|c|}
\hline \multirow[b]{2}{*}{ Test $\frac{11}{i t}$} & \multicolumn{2}{|c|}{ Sex Roles } & \multirow[b]{2}{*}{$d f$} & \multirow[b]{2}{*}{$t$} \\
\hline & Grouo 1 & Group 2 & & \\
\hline 1 & PMn, Fmin, FM, MF & $F F, \quad f m F$ & 78 & . 3009 \\
\hline 2 & Mn, MIm, MF & $F F, F f m, F M$ & 96 & .4129 \\
\hline 3 & Iini , Mfm & $F F, F f m, F i$ & 75 & .5226 \\
\hline 4 & InI, Mifm & $F F, F f m$ & 71 & $.8790 *$ \\
\hline 5 & MIII, IUF & $F F, F M$ & 37 & 2.4558 \\
\hline 6 & InTI & $\mathrm{FF}$, FH & 16 & $1.917++$ \\
\hline 7 & Inin, fmli, fri & $F F$, $f m F, M F$ & 78 & $1.5596+$ \\
\hline 8 & Thin, fmil, FH & $F F, f m F$ & 57 & 1.1556 \\
\hline 9 & InT, fmil & $F F, \quad f m F$ & 53 & 1.1580 \\
\hline 10 & Finit, Fin & $F F, \quad H F$ & 37 & $2.1416+++$ \\
\hline 11 & MIII, FM & $\mathrm{FF}$ & 16 & $2.6110+++$ \\
\hline 12 & MIII & $F F$ & 12 & $2.6238+t+$ \\
\hline 13 & Fin & MiF & 23 & $1.2767+$ \\
\hline 14 & PinI, fmil, $\mathrm{FH}$ & fmfm & 58 & $2.86+t+t+$ \\
\hline 15 & MTI, fmr, FH, INF & fmfm & 71 & 1.839 \\
\hline
\end{tabular}

A comparison of $\mathrm{H}-\mathrm{S}$ scores for groups along the Franck sex-role dimension (MII vs FF, EN) leaving out the maverick MF cell and the neutral hifm, ffm cells produced a difference significant at the .05 level. When the HF cell was included in the comparison there was no significant 
difference. A comparison of the Franck groups (IIM, Hfm vs EF, Ffm) without the deviant FPf and PFF cells resulted in a difference significant at .20 . When all six possible cells were compared (HM, Mfm, MF VSFF, Ffm, FM) the results were not significant.

A comparison of the six Gough cells in-S scores (HF, fmil, FH vs FE, ImE, NE) was significant at .10. While this result was not as strong as desired, it is in the expected direction. When the neutral groups were eliminated, (fmin and fmil) the results were significant at the .025 level. Testing the difference for the Gough groups (III, FI VS FF) without the neutral groups nor the maverick IIF group gave a difference significant at .01.

looking at just the extreme sex-role groups Invs FF resulted in a difference significant at .025. When comparing Horner's a posteriori masculine sex-role groups versus the ideal self-actualized group (MH, fmil, Fin, MF vs fmfm) a difference was found that was significant at .05 . However, the most striking result occurred with the comparison of the masculine Gough cells, without IF, vs Lansky's ideal person cell (III, fmil, FII vs fmfm). The difference between these groups is significant at .005 .

Interrelationshios. Past studies indicated that Gough and Franck scores were not correlated. Pearson Product homent correlations performed on our data indicate that neither il-S nor tachistoscope scores were correlated 
with Gough or Franck scores alone. (see Table VII). The hypotheses cells, which include both strong Franck and strong Gough influence, were needed to find a significant (negative) correlation between tachistoscope scores and if-S (test iflo). This finding and that of test \#I, that high tachistoscope aggression scores, irrespective of cell, are significantly negatively correlated with the $\mathrm{H}-\mathrm{S}$, were unexpected Iindings. The correlation had been predicted to occur but in a positive direction. The results of tests \#I and \#10 were a reversal of our hypotheses. (The significance of $\# 10$ is questionable since in a group of 17 tests, this low level significance could be obtained by chance.)

\section{TABIE VII}

POSSIBLE INIERRELATIONSHIPS OF THE TXPERIIENTAL HRASURES INVESTIGATED VITH THE USE OF PEARSON'S PRODUCT HOHEITT

\begin{tabular}{|c|c|c|c|}
\hline & Inter-Relatio & $\partial f$ & $\bar{x}$ \\
\hline$\frac{T}{2}$ & $\begin{array}{l}\text { HI Tac AEB Score corr } \text { in } \text { ii-S } \\
\text { Lo Tac Agg Score corr w li-S }\end{array}$ & $\begin{array}{l}13 \\
10\end{array}$ & $\begin{array}{r}-.71 \\
.26 \\
\end{array}$ \\
\hline $\begin{array}{l}3 \\
4 \\
5\end{array}$ & 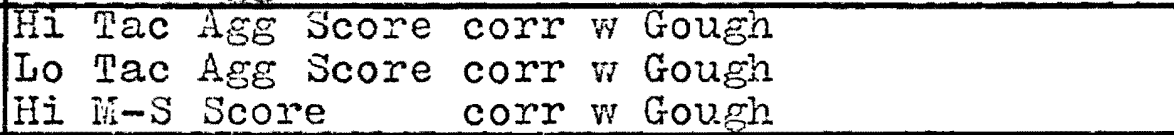 & $\begin{array}{l}13 \\
10 \\
24\end{array}$ & $\begin{array}{r}.04 \\
.48 \\
.03 \\
\end{array}$ \\
\hline $\begin{array}{l}6 \\
7 \\
8\end{array}$ & 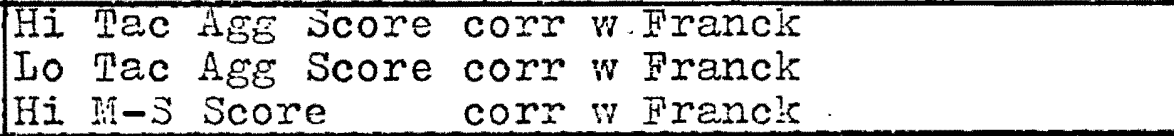 & $\begin{array}{l}13 \\
10 \\
24\end{array}$ & \\
\hline $\begin{array}{l}9 \\
10 \\
11 \\
12 \\
13 \\
14\end{array}$ & 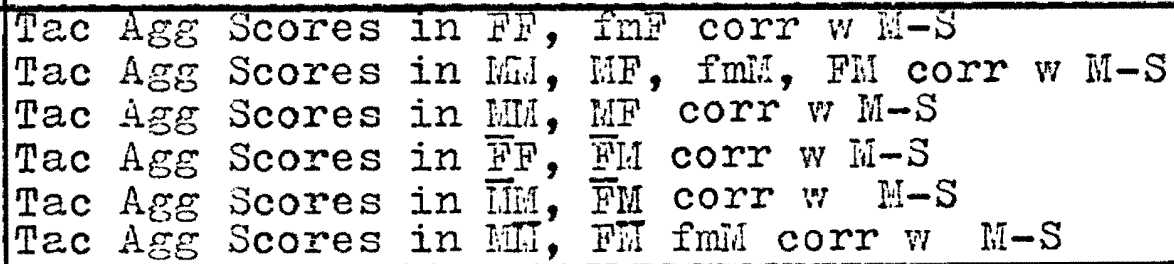 & $\begin{array}{r}17 \\
21 \\
11 \\
5 \\
7 \\
14\end{array}$ & $\begin{array}{r}.09 \\
-.35 \\
-.39 \\
.07 \\
-.07 \\
-.25\end{array}$ \\
\hline $\begin{array}{l}15 \\
16 \\
17\end{array}$ & $\begin{array}{l}\text { H-S Scores in FE corr w Gough Score } \\
\text { In-S Scores in FF, fmF corr w. Gough Score } \\
\text { In-S Scores in Fin corr w Gough Score }\end{array}$ & $\begin{array}{r}\frac{5}{5} \\
5\end{array}$ & $\begin{array}{r}.36 \\
-.06 \\
.23\end{array}$ \\
\hline
\end{tabular}




\section{CHAPTER IV}

\section{DISCUSSION}

Horner's a posteriori consideration of Iipinski's work included the new, untested, hypothesis that the addition of the IFF group to Iipinski's "masculine-oriented" group (HiI, fmin, FM) would have provided significant results. Horner further suggested that the cells Iin, fmil, Fil and MF "would have greater $\mathrm{H}-S$ than their more "female" oriented counterparts."

It was this lead that we followed in for formulation of our hypothesis groups: Iil, fmil, FI, IFF vS FF, fmF. The results of the tachistoscope task supported the validity of this grouping ( .005$)$ for the 4 aggressive stimuli. The results of the M-S task did not support the hypothesis regarding this grouping.

Within the four-picture grouping of aggressive scenes, two pictures ( $A_{1}$ and $A_{13}$ ) involve same-sex individuals ( 2 women) and two pictures ( $A_{2}$ and $A_{14}$ ) involve cross-sex aggression (a woman attacking $a$ man). It is interesting to note that the largest, though not significant, differences between the two groups occurred in relation to the crosssex scenes (see Table I). This suggests that aggression in a cross-sex situation is more frightening for the 
masculine group, than for more stereotyped feminine women. Same sex aggression, while apparently more taboo for both groups of women than it is for men, appears to elicit nearly the same response from both groups, i.e., less than for cross-sex aggression.

This observation of increased delay in recognizing aggressive scenes involving a woman attacking a man, particularly for group I (Fili, fml, FH, IFF), may be coupled with the additional observation of the Ss behavior in the dependency scenes. Here the differences are most notable in a reversed way, e.g., the largest and this time significant difference was with the same-sex picture. The Hypothesis group 1 took significantiy longer to recognize the scene portraying one women pleading with another $\left(D_{4}\right)$. This may suggest that more masculinely-oriented women (group 1) have different reactions to cross-sex aggression and same-sex dependency than femininely-oriented women (FF, fmF). Specifically, group 1 appears more frightened of both aggression against men and dependence on women than group 2.

A visual comparison of the performance of the hypothesis group 1 (NIH, fmp, HF, FM) on aggression and dependency with Kagan \& Hoss' male and female group is made in Figure 10.* The cross-sex pictures are seen to

*This is offered as an aid to understanding only. The recognition thresholds of male and female groups from the 


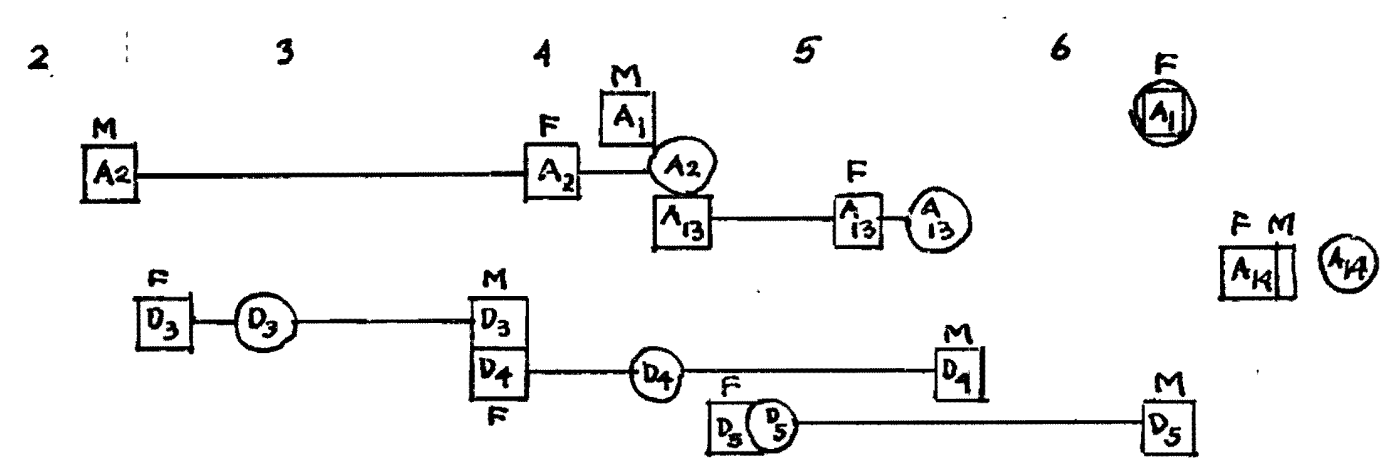

$M$ Kagan $r$ Moss: male group
$\square$ Kagan r Moss: female group
Group 1 (MM, fmM, MF, FM)

Figure 10. Speculative comparison with Kagan \& Hoss' results.

evoke exaggeratedly feminine behavior in the case of aggression and behavior in a masculine direction on the dependency scene of same-sex interaction. This illustration suggests that group $I$ has the worst of both worlds, i.e., women in Kagan and Hoss' study were more conflicted over aggression while men were more conflicted over dependency. Group 1 women are more conflicted than women in general over aggression and more conflicted, as men are,

* (cont.) Kagan and Moss study have been plotted. Then the recognition threshold for the hypothesis group 1 of this study were added so the direction of response could be visualized. 
over dependency -- in at least one area.

In an attemot to understand why a test of Hypothesis

1 and 4 (Horner's a posteriori conflict groups) did not show a significant difference in $M-S$, a test was done leaving out the maverick MF group. This changed the grouping from conflict cells to cells grouped along the Gough manifest-level of sex-role orientations. While the results were not significant, they were in the expected direction, i.e., masculine-oriented women would show higher M-S than feminine-oriented women. This may mean that in predicting $M-S$, a woman's conscious sex-role orientation may be the more powerful predictor. Using only those cells with strong sex-role identities and testing the conscious levels of identities produced results significant at $p .025$. Removing the maverick $N$ cell from this grouping intensified the results, p.01.

Lipinski's term 'maverick' for the ITF group proved to be particularly apt in our study. They were not predictable in the same direction in both cases, i.e., $\mathrm{M}-\mathrm{S}$ and fear of aggression. Their low M-S mean places them solidly in the feminine orientation, while their high fear of aggression mean switches them back to the hypothesis group. A better understanding of the $M F$ women may also give a solution to the contradictory negative correlation of $\mathrm{A}-\mathrm{S}$ and fear of aggression.

The WF group's mean indicates that their inclusion 
with FF would not weaken the difference significantly, yet it did reduce the strength of the significance markedly. Grouping the cells to test for significance along the latent level of sex-role identities, without the IF group, resulted in a difference significant at .05 .

When the maverick $M F$ group was included in this latent-level sex-role comparison, it not only weakened the significant difference, but the difference was lost.

Evidently both levels of sex-role identity nay be used to predict $\mathrm{M}-\mathrm{S}$ scores for women. However, using conscious sex-role identity as the predictor will enable one to do this with much greater certainty. If a woman falls in the MP cell, less could be said with reliability. Iipinski (1965) also found this group to be somewhat erratic in nAch.

Apparently, strength of $\mathrm{H}-\mathrm{S}$ is connected with some of the same traits that discriminate sex-role identities. The ability to be flexible may be the critical trait to discriminate best between the groups. The most significant difference was found in the comparison that included Iansky's ideal or normal fmfm, which he described as the group which is most able to remain flexible in coping with the demands of a complex world. He maintains they gain the flexibility by drawing on both "masculine" and "feminine" traits.

When looking at the means of the conscious masculine 
ability to be flexible.

; A higher overall level of $M-S$ was found in this study than was found in Horner's original study (1968), even though achievement for women is being encouraged at many levels. It would seem that it should be more acceptable and less risky for women to engage in achievement oriented activities now. Yet success and its consequences appear to continue to be fearful to many women. It is the authors' conclusion that women are still receiving a double-message from the culture. To be a successful professional and female is to risk social rejection and loss of self-esteem.

Suggestions for Future Research. A better tachistoscope test could be devised. While this measure, as used by Kagan and Inoss, was sensitive enough to isolate differences between men and women, the differences within the female population are smaller than that between female and male populations. Our results would have been more dramatic had the test been adjusted. In this particular experiment this change was not made in order that inferences could be drawn regarding the direction of change. Hore aggressive and dependent scenes would not only allow the within female population differences to be seen more vividly, but a variety of same-sex and cross-sex scenes might uncover an interpretable relationship with the MI-S. 
Another modification in design for future research would be to sample the omitted three sex-role groups (Mfm, fmfm, Ffm) for testing with the tachistoscope since unexpected relationships were found between $\mathrm{H}-\mathrm{S}$ and some fm groups, particularly, the ideal fmfm group. Since this group was not run on the tachistoscope in this experiment, no question regarding possible tachistoscope - II-S relationship for this group can be answered.

It may be worthwhile in future research to consider using a measure of flexibility in addition to the measures used in this study to test whether those women most conflicted in their sex-roles are also the least flexible.

We hope our findings will generate understanding of the conflicts women face when they choose to pursue a career. It is not enough that legislation makes it illegal to discriminate against women (a change in the explicit rules). More effort must be directed toward understanding the powerful psychological reasons (the implicit mules) which handicap women in their attempts to pursue a career and of which many women themselves are unaware. 


\section{BIBIIOGRAPHY}

Adams, Elsie and Hary Louise Briscoe 1971. "Up Against the Wall, Wother," Glencoe Press, Beverly Hills, Calif.

Adcock, Ngaire V. and G. I. litangan 1970. "Attention and Perceptual Jearning," The Journal of General Psycholozy, 33, 247-254.

Alper, Thelma G. 1974. "Achievement Rotivation in College Women: A Now-You-See-It-Now-You-Don't Phenomena," American Psychologist, 29(3), Narch, 194-203.

Atkinson, J.W. and N.T. Feather 1966. "A Theory of Achievement Hotivation," Wiley \& Sons, Inc., N.Y.

Bardwick, Judith and E.H. Douvan and ri.S. Horner and D. Gutman 1970. "Feminine Personality and Conflict," Brooks-Cole, Belmont, California.

Bardwick, Judith H. 1971. "Psychology of Women," Harper \& Row, New York.

Bardwick, Judith if. (ed.) 1972. "Readings on The Psychology of Women," Harper \& Row, Hew York.

Bruner, J.S. and I. Postman 1947. "Emotional Selectivity In Perception and Reaction," Journal of Personality, 16, 69-77.

Buss, Amold H. and Timothy C. Brock 1963a. "Repression and Guilt In Relation To Aggression," Journal of Abnormal and Social Psychology, 66, 345-350.

Buss, Arnold H. 1963b. "Physical Aggression in Relation To Different Frustrations," Journal of Aonormal and Social Psychology, $67,1-\overline{7}$.

Buss, Arnold H. 1966. "Instrumentality of Aggression, Feedback and Frustration as Deteminants of Physical Aggression," Journal of Personality and Social Psychology, 3, 153-162.

Coons, W.H. and Helen Annis 1970. "Worthington and Perceptual Defensiveness," Canadian Journal of Behavioral Science, 2(4). 
Davis, Fred and Virginia L. Olesen, 1965. "The Careet Outlook of Professionally Educated Homen," Psychiatry, $28,334-345$.

Deutsch, Helena 1944. "The Psychology of Women," Grune \& Stratton, New York.

Erikson, Erik H. 1951. "Sex Differences in Play Configurations of Pre-Adolescents," American Journal of Orthopsychiatry, 21, 667-692.

Farber, S.H. and R. H. Wilson 1963. "The Potential of Women," IncGraw-Hill, New York.

Fisher, S. 1973. "The Female Orgasm," Basic Books, Inc. N.Y.

Fontana, Gloria I.J. 1971. "An Investigation Into the Dynamics of Achievement Hotivation in ilomen," Dissertation Abstracts, 32 , (1821-B).

Franck, Kate 1945. note in Psychological Bulletin, 42(8), 535.

Franci, Kate 1946. "Preferences for Sex Symbols and Their Personality Correlates," Genetic Psychology Honographs, 33, 73-123.

Franck, Kate 1948, note in American Psychologist, 3(8), 350.

Franck, Kate and Ephraim Rosen 1949. "A Projective Test of Masculinity-Femininity," Joumal of Consulting Psychology, I3(4), 247-256.

Franck, Kate 1952. "Franck Drawing Completion Test," Australian Council for Education Research, Melbourne, Australia.

Freud, Sigrnund 1933. Chapter 5: "The Psychology of Vomen," In: New Introductory Lectures on Psycho-analysis, Norton, New York.

Glazer-Italbin, Nona and Helen Y. Waehrer 1972. "Woman In A Ilan-Hade World," Rand licNally, Chicago.

Goldiamond, I. 1958. "Indicators of Perception: Subliminal Perception, Subception, Unconscious Perception; an Analysis in Terms of Psychophysical Indicator Hethodology," Psychology Bulletin, 55, 373-411.

Gough, Harrison G. 1952. "Identifying Psychological Femininity," Educational and Psychological freasurements, 12, 427-439. 
Gough, Harrison G. 1969. "The CPI Hanual," Consulting Psychologists Press, Inc., Palo Alto, California.

Horner, Matina S. 1968a. "Sex Differences in Achievenent Wotivation and Performance in Competitive and NonCompetitive Situations" Unpublished doctoral dissertation, University of Michigan.

Horner, N.S. and W. Rhoem 1968b. "The litotive to Avoid Success as a Function of Age, Occupation and Progress at School," Unpublished manuscript, University of inichigan.

Horner, lfatina S. 1970. "Femininity and Successful Achievement: A Basic Inconsistency," In: J. Bardrick, et.al, "remininity Personality and Conflict," Brooks-Cole, Belmont, California.

Horner, Natina S. 1970. "Femininity and Successful Achievement: A Basic Inconsistency," In: Bardwick, Douvan, Horner and Gutman, "Feminine Personality and Conflict."

Horner, Hatina s. 1972a. "Fail: Bright Women," Psychology qoday, $3(6), 36 f f$.

Horner, liatina S. 1972b. "Toward an Understanding of Achievement Related Conflicts in Women," Journal of Social Issues, $28(2)$.

Horner, Matina s. 1972. "The Hotive to Avoid Success and Changing Aspirations of College Vomen," In: J.H. Bardwick $(e \bar{d})$, "Readings on the Psychology of Momen," Harper \& Row, New York.

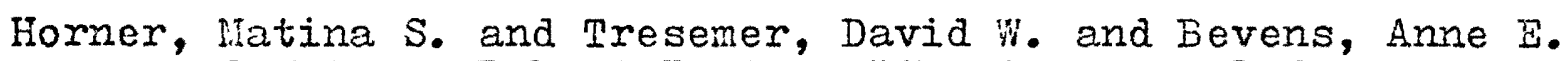
and Vatson, Robert I.,Jr., "Scoring Manual for an Empirically Derived Scoring System For Motive To Avoid Success," Unpublished Rranuscript, 31 Aug. 1973.

Kagan, Jerome \& Howard A lioss 1962. "Birth to lfaturity," John tiley \& Sons, Inc., N.Y. and London.

Komarovsky, M. 1972. "Cultural Contradictions and Sex Roles," In: J. Eardwick, "Readings on the Fsychology of Homen, Haxper and Row, N.Y.

Iansly, Leonard 1960. "Sex Identity and Defense Against Aggression," In: Hiller, "Inner Conflict and Defense," Henry Holt \& Co., New York. 
Lansky, Ieonard H., Vauginn J. Crandall, Jerome Kagan, and Charles T. Baker 1961. "Sex Differences in Agoression and Its Correlates in Hiddle-Class Adolescents," Child Development, 32, 45-58.

Lesser, G.S., Rhoda Krawitz, and Rita Packard 1963. "Experimental Arousal of Achievement motivation in Adolescent Girls," Journal of Abnormal and Social Psychology, 66, 59-66.

Ieventhal, D.B., K. R. Shemberg \& S. Kay Van Shoelandt,1968. "Effects of Sex-Role Adjustment Upon the Expression of Aggression," Journal of Personality and Social Psychology, 8, 393-396.

Leventhal, D.B. \& K.H. Shemoerg, 1969. "Sex-Role Adjustment and Non-sanctioned Aggression," Journal of Troperimental Research in Personality, 3(4), 233-286.

Lewis, E. 1968. "Developing Woman's Potential," Iowa State University Press, Amers, Iowa.

Lifshitz, Wichaela 1974. "Achievement Hotivation and Coping Behavior of Normal and Problematic Preadolescent

Kibbutz Children," Jr. Personality Assessment, 38(2), April, 138-143.

Iipinski, Beatrice 1965. "Sex Role Conflict and Achievement Hotivation in College Women," Unpublished doctoral dissertation, University of Cincinnati.

Hiaccoby, E. 1963. "Women's Intellect," In: S. Hi. Farber \& R. I. Wilson (eds.), "The Potential of Women," McGraw-Hill, New York.

Haccoby, Eleanor (ed) 1966. "The Development of Sex Differences," Stanford University Press, Stanford, Califormia.

Maccoby, E. 1972. "Sex Differences in Intellectual Functioning," In: J.i. Bardwick (ed), "Readings on the Psychology of Homen," Harper \& Row, New York.

Hannes, Harya 1963. "The Problems of Creative Homen;" In: S.M. Farber \& R. H. Wilson $(\in d s)$, "The Potential of Homen," iicGraw-Hill, New York.

HcKeachie, H.J. 1961. "Hotivation, Teaching Hethods and College Learning," In: H.R. Jones(ed), "Nebraska Symposium on Hotivation," University of Nebraska Press, 111-142. 
Mead, Hargaret 1949. "Wale and Female," . Morrow, New York.

Milgram, Stanley 1963. "Behavioral Study of Obedience," Journal of Abnormal and Social Psychology, 67, $371-378$.

Hiller, Daniel E., and Guy E. Swanson 1960. "Inner Conflict and Defense," Henry Holt and Co., New York.

Ovesey 1962. "Fear of Vocational Success," Archives of General Psychiatry, 7, 82-93.

National Nanpower Council, 1957.

Reed, Ilax R. 1957. "The liasculinity-Femininity Dimension in Normal and Psychotic Subjects," Journal of Abnormal and Social Psychology, $55(3), 289-294$.

Sauber, S. Richard 1971. "Locus of Control and Task Categorization: A Study Using the Perceptual Defense Paradigm," The Journal of Social Psychology, 85, $311-312$.

Schwenn, it. 1970. "Arousal of the hotive to Avoid Success," Unpublished honors thesis, Harvard.

Sears, R.R. 1961. "Relation of Early Socialization Experiences to Aggression in Iridale Childhood," Journal of Abnormal and social Psychology, 63, 466-492.

Sears, Robert R., Lucy Rau, and Richard Alpert 1965. "Identification and Child Rearing," Stanford University Press, Stanford, California.

Shemberg, K. M. and D. B. Ieventhal 1968. "MasculinityFemininity and Need for Social Approval," Journal of Projective Techniques \& Personality Assessment, 32(6) $575-577$.

Shepler, Bernard 1951. "A Comparison of Hasculinity-Femininity lieasures," Journal of Consulting Psychology, $15(6), 484-486$.

Sister Barbara Ann 1971. "irasculinity-Femininity in Creative Women," Dissertation Abstracts, $32(2411-B)$. 
Urbina, Susana, Joan B. Harrison, Charles E. Schaefer, \& Anne Anastasi 1970. "Relationship between MasculinityFemininity and Creativity as Measured by the Franck Drawing Completion Test," Psychological Reports, 26(3), 799-804.

Worthington, Alan G. 1970. "A Note on 'Tranquilizers and Perceptual Defensiveness'", Canadian Journal of Behavioral Science 2(4),

Zajone, R.B. 1962. "Response Suppression in Perceptual Defense," Journal of Experimental Psychology, 64, 206-214. 
Name :

Age :

Marital Status: Single: Unattached as yet Going steady Engagea

Miarried: How long Divorced?

\# of chilaren Widowed?

How many children are there in your family? Brothers Sisters

How many are younger than you? Brothers How many are older than you? Brothers Sisters Sisters

What is your father's occupation (if father is retired or deceased, what was his most recent full-time occupation)?

What was the highest level of schooling that your father attained? (Indicate degrees earned, if aporopriate.)

What if any, is your mother's occupation (consider here only paid employment)?

What percentage of her time does (or did) she devote to it?

What was the highest level of schooling that your mother attained? (Indicate degree earned if appropriate.)

What is your present vocational goal once your education is completed?

What is your major? (freshman, etc)?

What is your academic year

INSTRUCPIONS: on the following pages you will see two verbal leads or cues, and your task is to tell a story that is suggested to you by each cue. Try to imagine what is soing on in each. Then tell what the situation is, what led up to the situation, what the people are thiniring and feeling, and what they will do.

In other words, write as complete a story as you can -a story with plot and characters.

You will have twenty (20) seconds to look at a verbal cue and then 4 minutes to write your story about it. Write your first impressions and work ranidly. I will keep time and tell you when it is time to finish your story and to get ready for the next cue. 
There are no right or wrong stories or kinds of stories, so you may feel free to write whatever story is suggested to you when you look at a cue. Spelling, punctuation, and grammar are not important. That is important is to write out as fully and as quickly as possible the story that comes into your mind as you imagine what is going on in each cue.

Notice that there will be one page for writing each story following the cue. If you need more space for writing any story, use the reverse side of the cue page. 
After first term finals, Nancy finds herself at the top of her med school class. 
1. What is happening? Who are the persons?

2. What has led up to this situation? That is, what has happened in the past?

3. What is being thought? What is wanted? By whom?

4. That will happen? That will be done? 
59

Anne is sitting in a chair with a smile on her face. 
1. What is happening? Who are the persons?

2. What has led up to this situation? That is, what has happened in the past?

3. What is being thought? What is wanted? By Whom?

4. What will happen? ihat will be done? 
Directions: Circle $T$ if the item is true about you. Circle Fif the item is not true about you. Do all the items. This questionnaire is designed to take about 5 minutes to complete.

T F 1. I want to be an important person in the community.

I F 2. I'm not the type to be a political leader.

I $F$ 3. When someone talks agajnst certain groups or nationalities, I always speak up against such talk even though it makes me unpopular.

T F 4. I like mechanics magazines.

T $F$. I think I would like the work of a librarian.

T F 6. I'm pretty sure I know how we can settle the international problems we face today.

T F 7. I would never feel right if I thought I wasn't doing my share of the hard work of any group I belonged to.

T F 8. People seem naturally to turn to me when decisions have to be made.

T F 9. I must admit I feel sort of scared when I move to a strange place.

T F 10. I like to go to parties and other affairs where there is lots of loud fun.

T F 1l. If I were a reporter I would like very much to report news of the theater.

T F 12. I would like to be a nurse.

I F 13. It is hard for me to "bawl out" someone who is not doing his job properly.

T F 14. If I get too much change in a store $I$ always give it back.

T F 15. I very much like hunting.

I F 16. Some of my family have habits that bother and annoy me very much.

T F 17. I would like to be a soldier. 
T F 18. I think I could do better than most of the present politicians if I vere in office.

T F 19. I like to be with a crowd who play jokes on one another.

T $F$ 20. It is hard for me to start a conversation with strangers.

T F 21. I often get feelings like crawling, burning, tingling, or "going to sleep" in different parts of my body.

I F 22. I hate to have to mush when working.

I F 23. In school I was sometimes sent to the principal for cutting up.

T F 24. I think I would like the work of a building contractor.

I F 25. When I work at something I like to read and study about it.

I F 26. I think that I am stricter about right and wrong than most people.

T F 27. I am somewhat afraid of the dark.

T. $F$ 28. I am very slow in making up my mind.

T F 29. I am hardly ever bothered by a skin condition, such as athlete's foot, rash, etc.

T F 30. I like to boast about my achievements every now and then.

I F 3I. Sometimes I cross the street just to avoid meeting someone.

T F 32. I vould do almost anything on a dare.

T F 33. I think I would like to drive a racing car.

T 34 . I must admit that I enjoy playing practical jokes on people.

T F 35. I always tried to make the best school grades that I could.

T F 36. I am inclined to take things hard. 
T F 37. At times I feel like picking a fist fight with someone.

T F 38. I am apt to hide ny feelings in some things, to the point that people may hurt me without their knowing about it.

T F 39. Sometimes I have the same dream over and over.

T F 40. The thought of being in an automobile accident is very frightening to me.

T F 41. The average person is not able to appreciate art and music very well.

T F 42. I prefer a shower to a bath.

T F 43. I am often a little uneasy about handling lnives and other sharp-bladed instruments.

T $F$ 44. Sometimes I feel that I am about to go to pieces.

I F 45. I like adventure stories better than romantic stories.

T F 46. I like to be in many social activities.

T F 47. I was hardly ever spanked or whipped as a child.

I. F 48. I think I would like the work of a garage mechanic.

I F 49. A windstorm terrifies me.

T. F 50. I get very excited very easily.

T F 51. I become quite irritated when I see someone spit on the sidewalk.

T F 52. I think I would like the work of a dress designer.

I F 53. I have a certain talent for understanding the other person, and for sympathizing with his problems.

T F 54. It makes me very nervous when I get blamed for making a mistake.

T F 55. I often get disgusted with myself.

$T$ F 56. I always like to keep my things neat and tidy and in good order. 
T F 57. I think I would like the work of a clerk in a large department store.

T F 58. I get very tense and anxious when I think other people are disapproving of me.

On the following page you will find a number of incomplete drawings; please complete them. Do it any way you like; use as many lines as you wish; do it the way it seems most fun. There is no wrong or right way of doing this. We want to know what women can do in response to simple geometric dravings like these. It is necessary for you to complete all the drawings. 


$$
\begin{array}{|c|c|c|}
\hline 11 & f & 5 \\
\hline 4 & - & Z \\
\hline 3 & C & > \\
\hline H & \diamond & S \\
\hline
\end{array}
$$


Aggressive scenes

1 - A young woman is choking another young woman.

2 - A young woman is punching a young man.

13 - A young woman has hands above head and is holding a plate which she is about to throw at an older woman who is cowering.

14 - A young woman has her hands raised to the face of an older man as if to slap him.

Dependency scenes

3 - A young woman is on a stool with her head boved and arms around the waist of an adult of the opposite sex who is standing behind the central figure.

4 - A young woman is standing with hands out as if pleading with an adult of the same sex who is standing in the background with back to the central figure.

5 - A young woman is on her knees in front of an adult of the opposite sex. The woman on her knees is looking up to the standing adult as if imploring the latter.

Sexuality scenes

6 - A couple is in bathing suits on a beach. The man is over the woman and is kissing her.

7 - A standing couple is embracing and kissing.

Physical Harm scenes

8 - A young woman is falling backward in mid-air.

9 - A dog is attacking a young woman who is recoiling from the animal.

Control scenes

10 - A young man and woman are standing together looking up at a picture.

11 - Two men are standing while one lights the cigarette of the second one.

12 - Two women are standing together; one is handing the other a cup and saucer. 

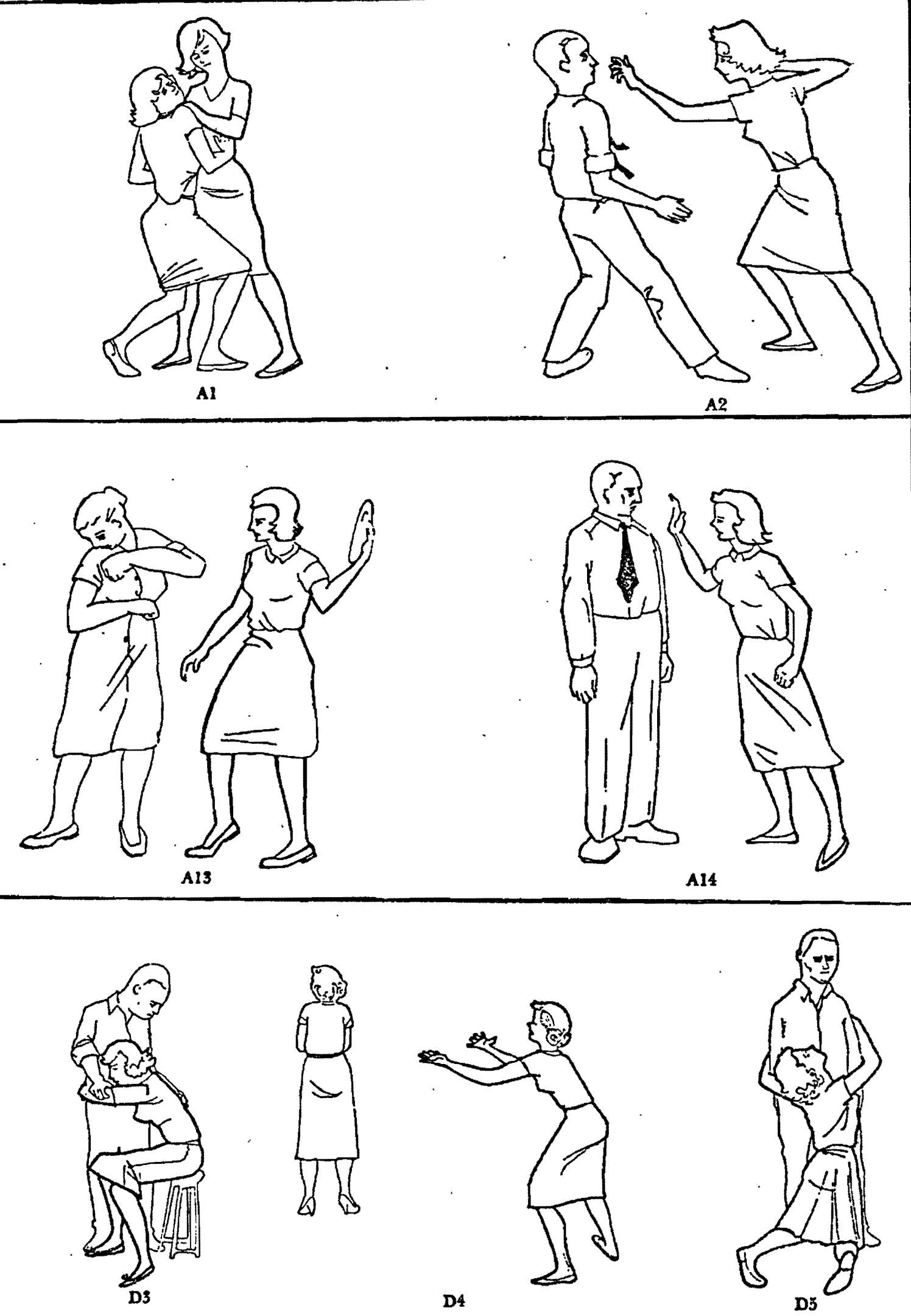


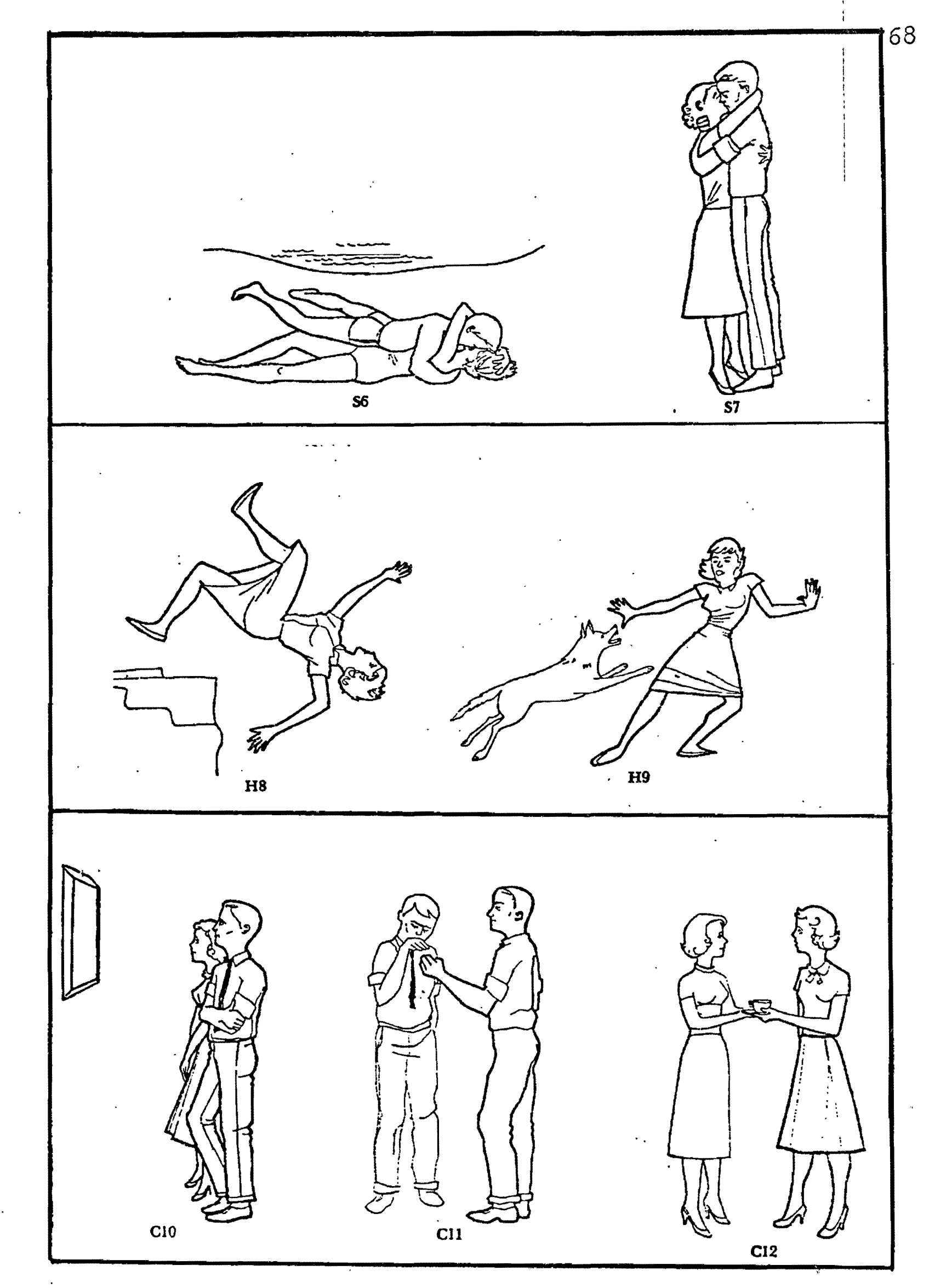


BEHN-MECCA Thesis Experiment

SUB JECT :

Exposure: Circle one $\left(\begin{array}{llllll}.01 & .02 & .04 & .10 & .50 & 1.0\end{array}\right)$

ORDIR: $\# 3$

Circle letter if $S$ passes (correctly identifies a stimulus)

D5 - A young woman is on her knees in front of a man. The woman is looking up to the man as if imploring him.

H8 - A young woman is falling backward in mid-air.

Al3 - A young woman has her hand above her head and holding a plate which she is about to throw at an older woman who is cowering.

A2 - A young woman is punching or lunging at a young man.

S6 - A couple in bathing suits on a beach. The man is over the woman and is kissing her.

Al - A young woman is choking another young woman.

D3 - A young woman is on a stool with head bowed and arms around the waist of a man who is standing in back of her.

C10 - A young man and woman are standing together looking up at a picture.

S7 - A standing couple is embracing and kissing.

CII - Two men are standing while one lights the cigarette of the other.

C12 - Two women are standing together; one is handing a cup and saucer to the second one.

D4 - A young woman is standing with hands out as if pleading with a woman who is standing in the background with her back to the young woman.

H9 - A dog is attacking a young woman who is recoiling from it.

Al4 - A young woman has her hana raised to the face of an older man as if she means to slap him. 